University of North Florida

UNIVERSITY of

NORTH FLORIDA

UNF Digital Commons

Fall 2006

\title{
Political Institutions and Economic Policy: Rural Renter Legislation in Argentina, 1912-1942
}

Andrés Alberto Gallo

University of North Florida, agallo@unf.edu

Follow this and additional works at: https://digitalcommons.unf.edu/beco_facpub

Part of the Economics Commons

\section{Recommended Citation}

Gallo, Andrés Alberto, "Political Institutions and Economic Policy: Rural Renter Legislation in Argentina, 1912-1942" (2006). Economics and Geography Faculty Publications. 1.

https://digitalcommons.unf.edu/beco_facpub/1

This Article is brought to you for free and open access by

the Department of Economics and Geography at UNF Digital Commons. It has been accepted for inclusion in Economics and Geography Faculty Publications by an authorized administrator of UNF Digital Commons. For more information, please contact Digital Projects.

(C) Fall 2006 All Rights Reserved

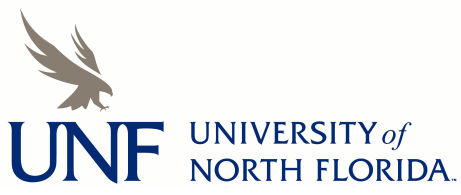




\title{
POLITICAL INSTITUTIONS AND ECONOMIC POLICY: RURAL RENTER LEGISLATION IN ARGENTINA, 1912-1942
}

\author{
ANDRÉS GALLO \\ University of North Florida ${ }^{a}$
}

\begin{abstract}
RESUMEN
La importancia de las instituciones políticas en el crecimiento económico en países en desarrollo no ha sido adecuadamente estudiada. El desarrollo económico argentino hacia fines del siglo XIX y principios del XX se basó en la producción agropecuaria de exportación. La estructura de producción se sostuvo con un sistema generalizado de contratos de arrendamientos. Este artículo utiliza análisis espacial y regresiones logísticas para estudiar el rol del Congreso Nacional en dar forma al marco legal de dichos contratos para el período 1912-1943. La principal conclusión es que las reformas legislativas fueron un producto del funcionamiento de las instituciones políticas en el Congreso, que proveyeron de poder de veto a los Conservadores para suavizar las reformas propuestas por los Radicales. El fraude electoral en los años treinta detuvo el proceso reformista en el Congreso y dio paso a cambios más revolucionarios a partir de 1940.
\end{abstract}

Palabras clave: Argentina 1912-1942, Instituciones, derechos de propiedad, crecimiento económico

a Department of Economics and Geography. Coggin College of Business. University of North Florida. 4567 St. Johns Bluff Road, South Jacksonville. Florida, 32224-2675. E-mail: agallo@unf.edu. 


\begin{abstract}
The importance of political institutions in the economic performance of developing countries is generally overlooked. Argentine economic development in the 19th and early 20 th centuries relied on the production of rural exports. The production structure in agriculture was supported by the widespread use of tenancy contracts. This paper uses spatial analysis and logistic regression to study the role of Congress in shaping tenancy legislation for the period 1912 to 1943 . The finding is that legislative reform was a product of how political institutions worked in Congress providing veto power to Conservatives over the proposals of Radicals. Electoral fraud in the 1930s stopped tenancy legislation and gave rise to revolutionary changes in the 1940s.
\end{abstract}

Keywords: Argentina 1912-1942, Institutions, property rights, economic growth

JEL Classification: N56, P16, P48, Q15, O17, D72

"Everyone desires and believes in land ownership. There is probably no society in the world whose members prize ownership of farm land more highly than Argentina and there is no conviction more widespread among Argentines than the idea that a wider distribution of land ownership would help to develop a better and more democratic social order. This conviction is shared alike by many owners of large tracts of rich Pampas land and more than 200,000 tenant farmers - large and small. Most city people, whether or not they know anything about rural life, quite generally believe the same thing» ${ }^{1}$.

\title{
1. INTRODUCTION
}

Argentina's economic development in the last part of the nineteenth century and the first decades of the twentieth century relied on the dynamism of its rural sector. Because of the concentration of land in few hands and the inability of Conservative governments to produce effective legislation to subdivide land in the Pampean region, production was structured around a widespread system of tenancy and sharecropping. Free market forces determined contractual relations according to the regulations laid down in the Constitution and the Civil Code ${ }^{2}$. Moreover,

\footnotetext{
1 Taylor, "Rural Life In Argentina», p. 174.

2 See Palacio, "Judges, Lawyers and Farmers»; Halperin Donghi, "Buenos Aires Landed Class»; Adelman, "Republic», and Hora, «Terratenientes».
} 
immigration of rural workers and farmers from Europe helped to foster a vigorous market for leasing. By 1912 about 65 per cent of all farms were under some type of leasing contract. As the population grew quickly and the economy boomed, the ensuing demand for land boosted rent and farm prices. Therefore, owners benefited most from the increase in prices. In 1912 the political system opened to democracy offering renters the opportunity to voice their concerns in the political arena. In the legislative election of 1914 a new political force, the Radical Party, won popular support and began to displace Conservatives from Congress and governmental offices. In 1916 the Radicals won the national presidential election and their leader, Hipolito Yrigoyen, became President.

The traditional view in Argentina's economic history is that, despite timid attempts, neither Conservatives nor Radicals pursued tenancy reform; only in the 1940s did a populist government introduce changes in legislation regarding tenancy. This paper analyses how democracy and congressional political institutions generated a tug of war between the representatives of owners and renters in Congress between 1912 and 1943, preventing the passage of comprehensive tenancy reform. The historical narrative is complemented by a spatial analysis of political preference and a logistic regression of roll call vote in Congress. These techniques facilitate an understanding of the political alignments in Congress with respect to tenancy reform and how political preferences evolved over time. Four major conclusions stem from the analysis of the evolutionary path of tenancy legislation during this period. First, Radicals and Conservatives had diverse constituencies which established different preferences for legislation, even though they shared a common vision of the broad economic model concerning rural exports. Second, Radicals voted for new legislation concerning rural rents, without trying to overthrow the tenancy system. They sought to improve living conditions in the countryside but still allowed markets to be the main instrument for resource allocation. Third, political institutions and veto points played a decisive role in shaping legislation throughout this period. The mild results in terms of regulatory changes were a product of the institutional setup of Congress, instead of simple lack of will from the government in office. Nonetheless, there were important changes in the 1930s moving towards stricter rent control and contract regulation legislation. Fourth, the particular political environment in the 1930s, electoral fraud and the lack of representation prevented the passage of new legislation and led to the revolutionary reforms during the Peronist era ${ }^{3}$.

\footnotetext{
3 See Alston and Gallo, "Erosion of Rule of Law».
} 


\section{THE IMPORTANCE OF RURAL RENTS IN ARGENTINA}

In the early twentieth century, tenancy contracts allowed land subdivision in the Pampean region without the need for significant land reforms or changes in property rights ${ }^{4}$. The economic and social situation in the Pampean region produced several results in terms of political demands, especially in agriculture, which differ from the situation in the rest of the country. First, since the second half of the nineteenth century, economic growth was driven by the exporting sector, with heavy reliance on cattle and agriculture (wheat, maize and flaxseed) from the Pampean region ${ }^{5}$. Those provinces outside the Pampas lacked crops or products to compete on international markets and were growing at much lower rates (Table 1$)^{6}$. Second, the economic opportunities in the Pampean region attracted European immigrants ${ }^{7}$. Most of the farmers coming to Argentina to work the land settled in this region ${ }^{8}$. The lack of open lands determined the extensive use of rents as a mechanism for subdivision of farming land (Table 2). As a result, the Pampean region had a high proportion of medium-sized farms and tenant farmers with political demands who had not been represented by the political system before 1912, but found better conditions when democracy was allowed (Table 3$)^{9}$.

TABLE 1

CEREAL PRODUCTION

\begin{tabular}{|c|c|c|c|c|c|c|}
\hline & \multicolumn{3}{|c|}{ Tons } & \multicolumn{3}{|c|}{ Percentage of the total } \\
\hline & Wheat & Maize & Linseed & Wheat & Maize & Linseed \\
\hline Buenos Aires. & $1,885,578$ & $2,488,032$ & 315,382 & 34.4 & 43.8 & 24.7 \\
\hline Santa Fe ......... & 965,107 & $1,780,400$ & 497,724 & 17.6 & 31.3 & 39.0 \\
\hline Cordoba.. & $1,682,562$ & 727,420 & 184,773 & 30.7 & 12.8 & 14.5 \\
\hline Entre Rios ........... & 256,827 & 78,800 & 243,543 & 4.7 & 1.4 & 19.1 \\
\hline La Pampa.. & 551,295 & 57,200 & 23,892 & 10.1 & 1.0 & 1.9 \\
\hline Other Provinces .... & 143,969 & 548,600 & 12,499 & 2.6 & 9.7 & 1.0 \\
\hline Total..................... & $5,485,338$ & $5,680,452$ & $1,277,813$ & 100.0 & 100.0 & 100.0 \\
\hline Total Pampean Region ....... & - & - & - & 97.4 & 90.3 & 99.0 \\
\hline
\end{tabular}

Source: Dirección de Estadística, Anuario Estadístico.

\footnotetext{
${ }^{4}$ See Adelman, "Frontier Development», and Taylor, "Latifundia».

5 See Díaz Alejandro, "Essays», and Di Tella and Zimelman, "Los ciclos».

6 See Diaz Alejandro, "Essays», and Rock, "Argentina».

7 See Solberg, "Peopling the Prairies», and Solberg, "Nationalism».

8 See Solberg, "Peopling the Prairies».

9 See Solberg, "Social Unrest»; Adelman, «Socialism and Democracy», and Walter, "Politics, Parties».
} 
TABLE 2

NUMBER OF RURAL ESTABLISHMENTS AND TENANCY

CEREALS AND LINSEED (EXCLUDING MAIZE)

Cereals and linseed (excluding maize)

\begin{tabular}{|c|c|c|c|c|c|c|}
\hline \multicolumn{7}{|c|}{ Renters plus Sharecroppers as $\%$ of total } \\
\hline Year & $\begin{array}{c}\text { Buenos } \\
\text { Aires } \\
(\%)\end{array}$ & $\begin{array}{c}\text { Santa } \\
\text { Fe } \\
(\%)\end{array}$ & $\begin{array}{c}\text { Córdoba } \\
(\%)\end{array}$ & $\begin{array}{c}\text { Entre } \\
\text { Rios } \\
(\%)\end{array}$ & $\begin{array}{c}\text { La } \\
\text { Pampa } \\
(\%)\end{array}$ & $\begin{array}{c}\text { Total } \\
\text { Pampean } \\
\text { Region } \\
(\%)\end{array}$ \\
\hline $1912 \ldots$ & 70.10 & 64.16 & 71.23 & 58.94 & 72.14 & 67.38 \\
\hline .................. & 64.90 & 66.34 & 66.40 & 55.92 & 64.59 & 64.30 \\
\hline 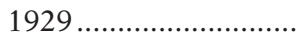 & 61.90 & 62.88 & 62.00 & 55.72 & 64.84 & 61.43 \\
\hline $1932 \ldots \ldots \ldots \ldots \ldots \ldots \ldots \ldots$ & 64.33 & 66.74 & 63.52 & 56.74 & 60.91 & 63.67 \\
\hline $1933 \ldots \ldots \ldots \ldots \ldots \ldots \ldots \ldots$ & 67.28 & 62.06 & 65.15 & 55.60 & 63.51 & 64.15 \\
\hline $1937(*) \ldots \ldots \ldots \ldots \ldots \ldots \ldots$ & 65.24 & 62.76 & 47.72 & 48.93 & 62.21 & 58.62 \\
\hline $1947(*)$..................... & 61.60 & 59.15 & 53.93 & 45.70 & 57.33 & 57.40 \\
\hline
\end{tabular}

$(*)$ Note: includes all types of rural establishments.

Source: Agricultural Census 1937 and Dirección de Estadística, Anuario Estadístico.

The increase in tenancy coincided with high economic growth and a boom of the exporting sector ${ }^{10}$. As has been shown in the literature, productivity and investment were similar on rented versus owned land ${ }^{11}$. Several factors led to an increased demand for reform in tenancy legislation. First, immigration of rural workers from Europe created an active market for tenancy contracts, increasing land demand and, consequently, rent and land prices ${ }^{12}$. Second, the settlement of agricultural land was completed by $1914^{13}$. Therefore, demographic pressure on the fixed productive factor produced the necessary conditions for the surge of protests by tenant farmers ${ }^{14}$. The first incident, which started a series

10 See Halperin-Donghi, "Argentine Export Economy»; Adelman, "Frontier Development», and Díaz Alejandro, "Essays».

11 See Taylor, "Latifundia»; Solberg, "Prairies and the Pampas»; Barsky, "Agro pampeano», and Tulchin, "Relationship».

12 See Taylor, "Peopling the Pampas».

13 See Adelman, "Frontier Development»; Cortés Conde, "Progreso Argentino»; Cortés Conde, "Vicissitudes», and Gallo and Cortes Conde, "Historia Argentina».

${ }_{14}$ Rural settlement in countries like Argentina, Canada and the United States generated different political tensions depending on the type of settlement process each country followed. "The outbreak of rural unrest in both Argentina and Canada in the years before the War signalled the end of the open frontier era. Not surprisingly, Argentine producers aimed their umbrage at landowners, while Canadian farmers excoriated banks and the distant federal government. It was no longer self-evident that the system of property relations which appeared so promising in the 1890s, could sustain continued expansion on either the pampas 
TABLE 3

DISTRIBUTION OF LAND POSSESSION

\begin{tabular}{|c|c|c|c|c|c|c|c|c|}
\hline & \multicolumn{4}{|c|}{$\begin{array}{l}\text { Pampean Region } \\
\text { (Thousands) }\end{array}$} & \multicolumn{4}{|c|}{$\begin{array}{l}\text { Rest of the Country } \\
\text { (Thousands) }\end{array}$} \\
\hline & \multicolumn{2}{|c|}{1914} & \multicolumn{2}{|c|}{1937} & \multicolumn{2}{|c|}{1914} & \multicolumn{2}{|c|}{1937} \\
\hline & No. & Hectares & No. & Hectares & No. & Hectares & No. & Hectares \\
\hline Total.. & 189,2 & 67,242 & 266,9 & 67,692 & 117,3 & 95,652 & 167,5 & 106,910 \\
\hline $0-25 \ldots \ldots \ldots . .$. & 43,5 & 480 & 58,0 & 696 & 57,2 & 484 & 91,6 & 858 \\
\hline $26-100 \ldots \ldots$. & 55,9 & 3,428 & 90,1 & 5,549 & 24,0 & 1,388 & 37,1 & 2,096 \\
\hline $101-500 \ldots$. & 70,6 & 15,885 & 102,2 & 24,288 & 16,0 & 3,962 & 19,6 & 5,446 \\
\hline $501-1000 \ldots$ & 9,0 & 6,231 & 9,5 & 8,984 & 4,8 & 3,413 & 6,9 & 6,559 \\
\hline 1001-5000. & 8,1 & 18,463 & 4,9 & 12,731 & 11,8 & 29,488 & 8,0 & 20,583 \\
\hline $5000+\ldots \ldots \ldots$ & 1,9 & 22,752 & 1,9 & 15,443 & 3,3 & 56,914 & 3,9 & 71,365 \\
\hline \multicolumn{9}{|c|}{ Percentage } \\
\hline $0-25 \ldots \ldots \ldots . .$. & 23.0 & 0.7 & 21.7 & 1.0 & 48.8 & 0.5 & 54.7 & 0.8 \\
\hline $26-100 \ldots \ldots$. & 29.6 & 5.1 & 33.8 & 8.2 & 20.5 & 1.5 & 22.2 & 2.0 \\
\hline $101-500 \ldots$. & 37.3 & 23.6 & 38.3 & 35.9 & 13.7 & 4.1 & 11.7 & 5.1 \\
\hline $501-1000 \ldots$ & 4.8 & 9.3 & 3.6 & 13.3 & 4.1 & 3.6 & 4.2 & 6.1 \\
\hline 1001-5000. & 4.3 & 27.5 & 1.9 & 18.8 & 10.1 & 30.8 & 4.8 & 19.3 \\
\hline \multirow[t]{3}{*}{$5000+\ldots \ldots \ldots$} & 1.0 & 33.8 & 0.7 & 22.8 & 2.8 & 59.5 & 2.4 & 66.8 \\
\hline & \multicolumn{2}{|c|}{ Average } & \multicolumn{2}{|c|}{ Average } & \multicolumn{2}{|c|}{ Average } & \multicolumn{2}{|c|}{ Average } \\
\hline & Area & 1914 & Area & 1937 & Area & 1914 & Area & 1937 \\
\hline Total..... & & 355 & & 254 & & 815 & & 638 \\
\hline $0-25 \ldots \ldots \ldots . .$. & & 11 & & 12 & & 8 & & 9 \\
\hline $26-100 \ldots \ldots$. & & 61 & & 62 & & 58 & & 56 \\
\hline $101-500 \ldots$. & & 225 & & 237 & & 247 & & 278 \\
\hline $501-1000 \ldots$ & & 688 & & 938 & & 707 & & 938 \\
\hline 1001-5000. & & 2,269 & & 2,573 & & 2,487 & & 2,544 \\
\hline $5000+\ldots$ & & 11,807 & & 8,094 & & 17,215 & & 17,918 \\
\hline
\end{tabular}

Source: Agricultural Census 1914 and 1937.

of proposals for legislation favoring tenant farmers, was the rural strike in 1912, known as El grito de Alcorta, which resulted in the creation of the FAA (Federacion Agraria Argentina), the main organization defending the rights of small farmers and tenants ${ }^{15}$. The main issues voiced by tenant farmers throughout the Pampean region were: lower rents, longer

or the prairies». Adelman, «Frontier Development», p. 261. See also Adelman, "The Social Bases of Technical Change».

15 See Solberg, "Prairies and the Pampas»; Ansaldi, "Conflicto obrero-rurales pampeanos»; Solberg, "Rural Unrest», and Arcondo, "El conflicto agrario». 
POLITICAL INSTITUTIONS AND ECONOMIC POLICY: RURAL RENTER LEGISLATION...

contract terms, compensation for improvements to rented land and freedom to contract with third parties for buying farm machinery and tools ${ }^{16}$. The political changes happening at this moment of Argentine history gave renters the opportunity to reach Congress with their requests.

\section{DEMOCRACY, POWER AND VETO POWERS IN CONGRESS: 1912-1921}

One of the most revolutionary changes in Argentine political institutions was the opening of the political system in 1912 through the Ley Saenz Peña. This law implemented two comprehensive reforms necessary in a democracy - the secret ballot and a reform of the electoral roll ${ }^{17}$. As a result of these reforms, local political leaders could no longer control voting and many types of fraud were eliminated even though the nomination process continued to be controlled by the party elite ${ }^{18}$. These reforms were brought about by the Radical party's pressure on the Conservative government by refusing to engage in any election ${ }^{19}$. Thus, part of the motivation to reform voting laws was to bring the Radicals into the system and reduce confrontation ${ }^{20}$.

The real difference between Radicals and Conservatives in terms of political preference is an issue far from being settled in Argentine historiography. Electoral support for the Radicals came from middle classes in both urban and rural areas, forming a coalition with the members of the elite who controlled the party leadership ${ }^{21}$. As Dario Canton (1966) demonstrates, the economic class background of Radical and Conservative Congressmen in 1916 did not differ, with 33 per cent of the Deputies of each group coming from high-income classes. Nonetheless, the Radical party had a larger representation of immigrants in Congress than did the Conservatives. Furthermore, as shown by Peter Smith (1974), in the years following 1916, the majority of Radical Congressmen came from the middle classes in contrast to the Conservative congressmen's aristocratic origins. The tension between aristocrats and the mid-

\footnotetext{
16 See Solberg, "Rural Unrest».

17 See Rock, "Politics in Argentina»; Smith, "Argentina», and Botana, "El orden conservador».

18 See Rock, "Politics in Argentina»; Smith, «Argentina», and Jones, Saiegh, Spiller and Tommasi, "Amateur Legislators-Professional Politicians».

19 See Rock, "Politics in Argentina»; Botana, "El orden conservador», Gallo and Conde, "Historia Argentina», and Halperin Donghi, «Buenos Aires».

${ }^{20}$ See Yablon, "Patronage, Corruption and Political Culture».

21 See Yablon, "Patronage, Corruption and Political Culture».
} 
dle class within the Radical Party produced severe strains leading to a definitive split in the $1920 \mathrm{~s}^{22}$. However, because of the middle-class nature of the Radical party, the traditional view has been that the Radicals did not propose a drastic departure from the economic policy of Conservative governments, given their shared vision of the rural-export economy ${ }^{23}$. To the contrary, this paper shows that despite the similarities in economic policy between Radical and Conservative governments, the Radical party, being a party of the masses and having to win the popular vote, was subject to strong pressure from its electorate and was therefore aligned with the demands of the majority of the electorate in rural areas, i.e. small farmers and tenants, while the Conservatives continued to maintain their close ties with the big landowners of the Pampas ${ }^{24}$. As a consequence, even though Radicals shared common political goals with Conservatives, the political demands of tenant and small farmers created enough pressure on the legislators of the Radical, Socialistas and Democrata Progresistas to promote new legislation ${ }^{25}$. Furthermore, if we look at the final legislation enacted by Congress it seems that the Radicals did not try to introduce important reforms. However, if we look at the initial bill and how it was reformed by Congress, especially the Senate, we can appreciate the importance of the political institutions, the effective blocking of legislation by the Conservatives in the Senate and the differences in preferences between legislators.

Because members of the Chamber of Deputies were elected by popular vote (unlike Senators) they were strongly affected by the Saenz. Peña Law $^{26}$. Since the turnover of seats in the Chamber of Deputies was gradual, it took four years, i.e. three elections, for the Radical party to obtain the majority of seats (Table 4$)^{27}$. The increase in seats won by the

22 See Ansaldi, "Profetas de cambios»; Ansaldi, "Caso de nomenclaturas»; Rock, "Politics in Argentina», and Smith, "Argentina».

${ }^{23}$ See Pucciarelli, "Conservadores, Radicales e Yrigoyenistas»; Rock, "Politics in Argentina»; Rock, "Radical Populism»; Smith, "Los radicals argentinos»; Solberg, "Social unrest»; Walter, "Politics, Parties»; Ansaldi, "Caso de nomenclaturas»; Ansaldi "Profetas de cambio», and Giacobone, "Radicalismo».

24 «In Congress, UCR deputies from the province generally — although not always- supported the passage of social legislation and measures to aid small farmers. Generally, also in contrast with the Conservatives, the Radicals tended to support more equitable, distributive economic policies, the gradual absorption of foreigners into the political process and stronger controls on the activities of foreign economic enterprises». See Walter, "Elections», at 717 .

25 See Solberg, "Rural Unrest», and Halperin Donghi, «Intimations».

${ }^{26}$ Each province was an electoral district for the election of Deputies. Each party presented an open list of Deputies. Candidates could be removed from the list.

${ }^{27}$ Deputies are elected for four years and half the chamber is renewed every two years. Senators are elected by the Provinces' legislatures and have tenure for nine years. A third of the chamber's seats are renewed every three years. 
Radical party resulted from the decline of the share of provincial Conservative parties ${ }^{28}$. However, due to the fact that local elections were held under different regulations from national elections, the Conservatives were able to maintain their political power locally and, as a result, continued to control Provincial governments and the Senate, but lost the Chamber of Deputies (Table 4$)^{29}$. As Table 4 shows, Radicals and Conservatives were not homogeneous parties with the same structure and constituencies in every province. Each province had its own characteristics, which affected the preferences of representatives. As such, different branches of the Conservatives had different names in each province reflecting the characteristics of the local politics (Table 4). The fragmentation of politics in Argentina is well documented and goes back to the early stages of the institutional formation of the country ${ }^{30}$. The Radical and Socialist parties were the first to attempt to create homogeneous political bodies throughout the country. This paper separates Deputies in Congress according to their political affiliation and the region they came from. In the case of the many Conservative parties, representatives from different provinces are grouped together in Congress despite the differences which existed between them. Even though this division simplifies the situation, it allows us to evaluate how the issue of rural rent regulations separated the political spectrum into two well-defined groups. Even though the relationship between representatives and socioeconomic actors is not straightforward, tis is a period in which democracy is in flux and actors and representatives are learning to deal with the new system. This paper facilitates an understanding of how social demands were filtered through the political system. As such, it analyzes actual voting behavior in Congress which, despite the ideological ties of each Congressman or party, determined the final legislation for the country.

Congress was the main vehicle for the passage of new legislation. An important group within the Chamber of Deputies was the Agriculture Committee which handled all bills coming into the Chamber; the Committee debated bills and had the power to stall or to change a bill before sending it to the floor. Therefore, the parties and regions represented in the Committee played an important role in the production of the final bills.

28 See Giacobone and Gallo, «Radicalismo bonaerense».

29 The provincial legislatures elected the Senators for the Provinces. Accordingly, they represented the majority of the Legislature which in most cases was from the same party as the Governor. During this period, the Conservatives controlled the elections at local level and were able to maintain the majority of the seats in the Senate.

30 See Rock, "State Building»; Rock, "Politics in Argentina»; Botana, "El orden conservador»; Gallo and Conde "Historia Argentina», and Halperin Donghi, "Buenos Aires». 
TABLE 4

CHAMBER OF DEPUTIES AND SENATE COMPOSITION: 1914-20

(Percentage of seats)

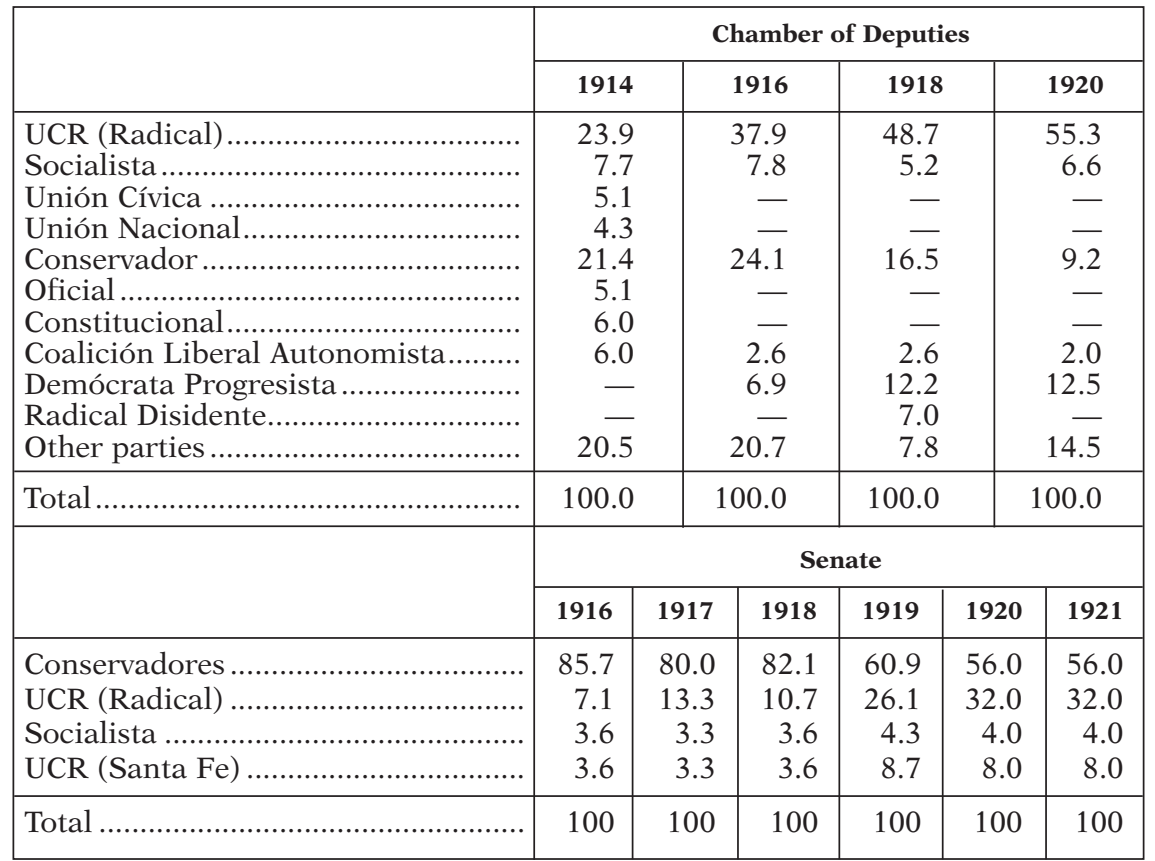

Source: Molinelli, 1999.

During this period, the Committees in both Chambers controlled both the characteristics of a bill and its agenda. Although party leaders of the Chamber or even the Executive Power could influence Committee members to send a bill to the floor or to delay it, the control of the Agriculture Committee was still a key factor in producing a bill and passing it on to the floor. As the Radical party gained seats in the Chamber of Deputies they increased their participation in the Committee. It is interesting to notice how, until 1914, the majority of the Committee members were from provinces outside the Pampean region but, by 1920 , all Committee members came from the Pampas. The Radicals, Socialistas and Democrata Progresistas controlled the Committee ${ }^{31}$.

Unlike the Chamber of Deputies, the distribution of political forces in the Senate did not change much after the reforms to the electoral law,

31 See Gallo, "Political Economy». 
POLITICAL INSTITUTIONS AND ECONOMIC POLICY: RURAL RENTER LEGISLATION...

allowing Conservatives to maintain the majority of the seats (Table 4). Thus, the experience of the Radical government is one of divided government with the Conservatives having a key veto power in the Senate ${ }^{32}$. Conservatives also controlled the Senate Agriculture Committee. Most of the members of this Committee came from provinces outside the Pampean region ${ }^{33}$.

\section{TENANCY LAWS OF THE FIRST RADICAL GOBERNMENT: 1916-1922}

The Radical administration proposed few bills for tenancy reforms: In 1917, Yrigoyen sent a homestead bill called La Ley del Hogar and another bill which would have created an Agriculture Bank, neither of which were passed by Congress ${ }^{34}$ and, as a result, until 1919 only a few tenant farmers' bills were presented in Congress. The first bills proposed by the Socialistas were a direct outcome of the Grito de Alcorta strike. It is important to notice how the number of bills in the Chamber of Deputies increased along with the number of seats gained by the Radicals (Figure 2). The Executive Power tried to introduce tenancy legislation in 1919 but, as illustrated in this section, despite the interest of the government and the Chamber of Deputies in enacting tenancy legislation, the veto power of the Conservatives in the Senate did not leave much room for thorough reforms. As a result, the legislation enacted was modest or even ineffective. Furthermore, loopholes in the laws, coupled with a low level of enforcement, did not revolutionize the tenancy structure of the Pampas ${ }^{35}$.

Even in the face of such strong opposition a willingness to reform, which was the result of several factors, continued to exist. First, the recession produced by the international market crisis caused by the Great War affected rural areas and renters ${ }^{36}$. Second, protests in the rural areas of the Pampean region became more vigorous, leading to several strikes and demonstrations after 1912. Third, the Radical party gained the majority of the Seats in the Chamber of Deputies in the 1918 election (Table 4). Finally, the Radicals and other allied parties controlled the Agriculture Committee ${ }^{37}$.

\footnotetext{
32 See Rock, «Argentina».

33 See Gallo, "Political Economy».

34 See Solberg, "Prairies and the Pampas».

35 See Palacio, "Judges, Lawyers and Farmers».

36 See Díaz Alejandro, "Essays».

37 See Gallo, "Political Economy».
} 
The Executive Power sent a bill to the Chamber of Deputies on July 2nd $1919^{38}$ which became the building block used by the Agriculture Committee to draft the bill sent to the floor ${ }^{39}$. The Committee made substantial changes to the Executive Power's bill by limiting and removing many of the proposed reforms (Table 5). Although this seems difficult to understand, it may be seen as stemming from two main causes. First, as mentioned before, the tension between the two different branches of the Radical party could have influenced the drafting of the law and Deputies coming from smaller provinces, where renters had but little influence on elections, may not have supported the reforms. Second, the Chamber of Deputies may have been employing a strategy of appeasement because of the strong opposition to the bill in the Senate. By reducing the number of reforms in the bill, they could persuade the Senate to vote favorably. In the end, the bill sent to the floor attempted to satisfy renters' demands by fixing contract terms to three years, prohibiting subleases, mandating that owners refund to renters certain costs of improvements to the land, allowing renters freedom to contract with third parties and several other regulations.

On September 21st 1920, the Chamber of Deputies debated the bill sent to the floor by the Agriculture Committee (Table 5) ${ }^{40}$. This bill closely resembled, finally, most of the petitions tenant farmers had presented during the Grito de Alcorta in 1912 and the petition of the Federacion Agraria Argentina (FAA) made to Congress ${ }^{41}$.

Despite the improvements in contracting conditions for tenant farmers, Deputies were aware of the limitations imposed on the freedom to contract but justified them for social needs: «To satisfy this [Social] need to reform control of agricultural contracting, we had to admit certain limits to the contracting freedom, but these limits do not curtail the basic freedom and are required for social order, stability and interest» ${ }^{42}$.

Deputies attempted to exchange efficiency for equity by giving certain rights to the rural renters. For example, the bill proposed granting land tenure stability to renters, compensating for improvements to the land, granting freedom to contract and restricting seizure of some work tools, animals and seeds ${ }^{43}$. However, the Conservatives voiced their discontent, claiming that tenants often failed to respect their contracts and sugges-

\footnotetext{
38 HCD, 1919.

39 HCD, September 21st 1920, Reunión 53, p. 323.

${ }^{40}$ HCD, Reunión 52, September 21st 1921, p. 322.

${ }^{41}$ Federación Agraria Argentina, July 13th, 1920, HCD, Reunión 24, p. 178.

42 Isaac Francioni (UCR) Santa Fe, HCD, Reunión 53, September 21st 1920, p. 342.

43 Nicolas Repetto (P. Socialista) Cap. Federal, HCD, Reunión 53, September 21st 1920, p. 351 .
} 


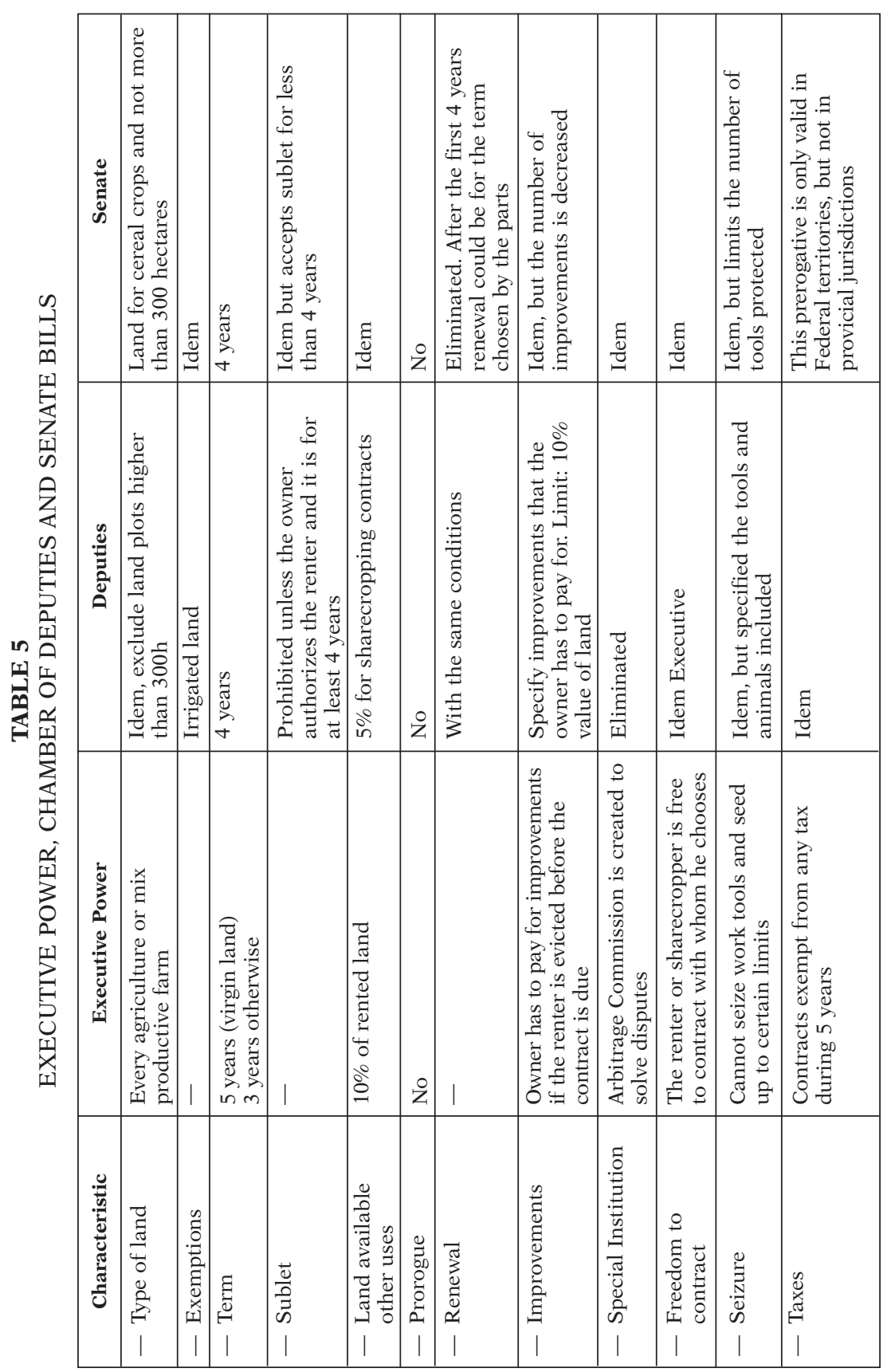




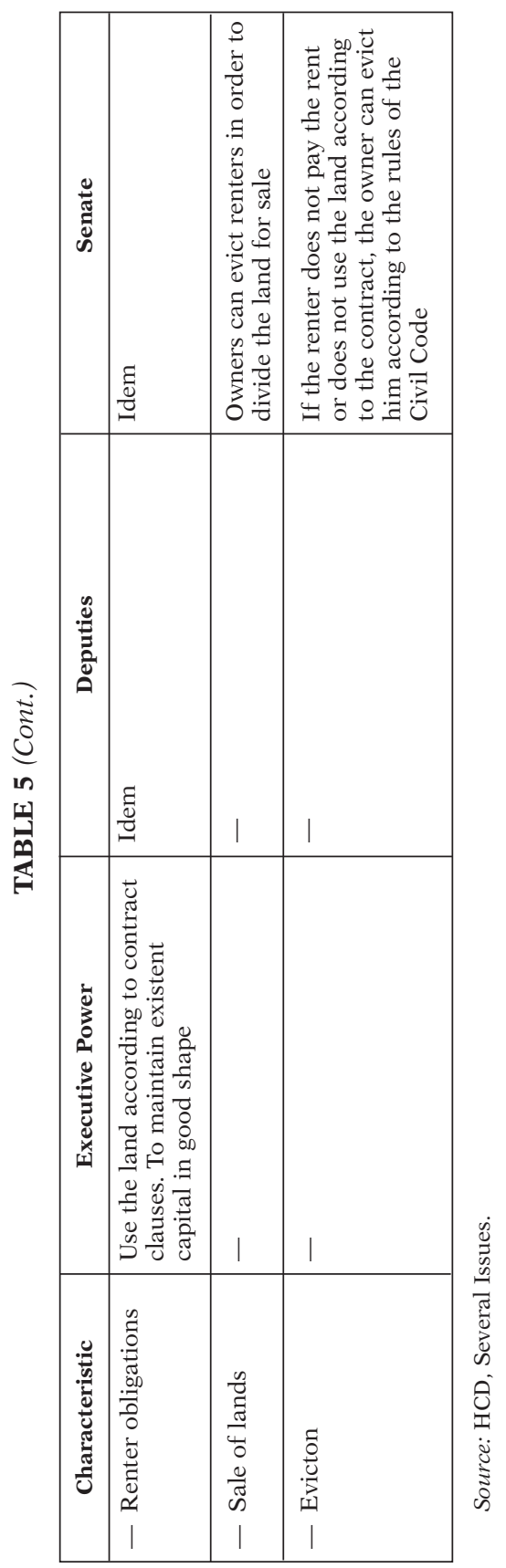


ting that the instability in the length of contract terms might well be due to the irresponsibility of tenants rather than owners ${ }^{44}$. The Chamber of Deputies passed the bill on September 27th $1920^{45}$. The bill met strong opposition in the Senate when it arrived on September 30th 1920 and it was sent to the Agriculture and Codes Committee where it was shelved ${ }^{46}$. In 1921, after a massive protest of farmers in front of the Congress, the Senate agreed to consider the bill ${ }^{47}$. The Agriculture and Code Committee sent the bill to the floor on September 20, $1921^{48}$. Nonetheless, some Senators voiced their disapproval of the farmers who marched to the Federal Capital and Congress to protest:

"They came here from I do not know what towns or in representation of what farmers and had incredible signs, and they marched to the Congress singing Le Marseilles, or something I have never understood, because their music had a tendency or tone that was close to "Leninism". (Laughs from other Senators)» ${ }^{49}$.

As expected, the Senate significantly reduced the reforms introduced by the Chamber of Deputies before passing the bill (Table 5). The preferences of Senators were different from those of Deputies and the Executive. Most Senators considered this unrest a local problem for the Pampean region and therefore did not want the law to be extended to the whole country. They wanted to protect their own jurisdictions from such a regulation:

"It is without doubt that, in general, this bill was conceived with a spirit of localism; in its broad characteristics it does not apply to other regions, regions that we have not fully examined or regions that have not been subject to conflicts. The bill coming from the Chamber of Deputies had these deficiencies. Perhaps, the bills' authors had in mind the region affected by the 1912 conflicts, that is, the Southern region of the Province of Santa Fe, Center of La Pampa, part of the Province of Buenos Aires and South of Cordoba» ${ }^{50}$.

${ }^{44}$ HCD, Reunión 53, September 21st 1920, pp. 345 and 349.

45 HCD, Reunión 57, September 27th 1921, pp. 606-621.

46 Honorable Camara de Senadores (HCS), Reunion 53, 43a Sesión Ordinaria, September 30th 1920, p. 1257.

47 See Solberg, "Prairies and the Pampas».

48 HCS, Reunión 46, 31a Sesión Ordinaria, September 30th 1921, p. 488.

49 Senator Garcia, HCS, Reunión 46, 31a Sesión Ordinaria, September 20th 1921, p. 495.

50 Senator Caballero, Diario de Sesiones, HCS, Reunión 46, 31a Sesión Ordinaria, September 20th 1921, pp. 493-494. 
Accordingly, the bill underwent some significant changes in an effort to reduce the loss of owners' rights. First, it was amended so that it would apply only to land rented for cereal production (Table 5). This change was crucial in convincing Senators to accept the four-year term for tenancy contracts. Many Senators were against the four-year term, mentioning the advantages of short-term contracts as a way of selecting good renters and avoiding agency problems ${ }^{51}$. Because of the strong opposition to the four-year term, it seemed the law would not be passed; however, once a Radical Senator proposed changing the first article, limiting the application of the law to rent contracts for cereal production only, the day was saved for the Radicals and the farmers ${ }^{52}$. By limiting the regulation to cereal areas, that is, the Pampean region, and leaving the rest of the country free from any regulation, the Radicals were able to pass the law since Senators from the other provinces ceased their opposition.

The Senate also introduced other changes. They removed the article governing renewal of contracts after the four-year term, thereby giving flexibility to both parties on successive renewals (Table 5). They modified the article concerning subletting giving the renter the opportunity to sublet for a period shorter than the one established by Deputies (Table 5). Furthermore, they included two extra articles with specific owners' rights and renters' duties. First, the owner could evict renters in the case of division of the land for sale. Second, the owner could evict if the renter did not comply with clauses in the contract. Finally, Senators protected the tax base of their provinces by limiting tax exemption of contracts to Federal territories.

As a result of the modifications the Senate achieved its objective by limiting the law to the richest part of the country and leaving most of the provinces exempt from regulation. The approved bill came back to the Chamber of Deputies on September 28th 1922. The members of the Agriculture Committee wanted Deputies to approve the bill as it came from Senate without any further debate, fearing that any delay would risk its passage. The members of the Committee played down the importance of the changes introduced by the Senate ${ }^{53}$ and two influential members of the Committee, Juan B. Justo (Socialista) and J. R.

51 Senator Luis Linares (Conservative), from Salta. HCS, September 24th, 1921, pp. 574576.

52 Senator Julio A. Roca (Conservative), from Cordoba. HCS, September 24th, 1921, pp. 577-578.

${ }_{53}$ It is interesting to note that that the Agricultural Committee gave the Deputies a copy of the bill approved by the Senate in which the part of the first article where the clauses of the law were limited to lands producing cereals was missing. Consequently the Chamber of Deputies voted the law without knowing the existence of this clause. 
Rodriguez (Radical), insisted that their colleagues vote in closed session with only one general vote to accept or reject the bill. The proposal was accepted and the bill was passed. This maneuver to gain a quick approval from the Deputies illustrates the difficulties the Radicals, Socialistas and Democratas Progresistas experienced in the Senate and suggests the contempt they had for the modified law. Law 11,170, enacted in 1921, was the first regulatory norm for rural rents created in Argentina.

\section{THE SECOND REFORM: 1929}

From 1922 to 1928, Marcelo T. de Alvear succeeded Yrigoyen as President of the country. Alvear came from the same party as Yrigoyen but had a different political orientation ${ }^{54}$. Even though he won the election with the explicit support of Yrigoyen, he formed a group within the Radicals, called the UCR Antipersonalista, which was actually closer to the Conservative party's policies ${ }^{55}$. By 1924, the division in the Radical party into Personalistas (followers of Yrigoyen) and Antipersonalistas was formalized ${ }^{56}$. The division of the Radicals in Congress made it much more difficult to pass any bill reforming rural renter legislation. Throughout Alvear's presidency all initiatives on rural legislation were stalled in Congress or never debated at all. In the two years following the approval of Law 11,170 in 1921 a few tenancy bills appeared in the Chamber of Deputies but Congress never considered them.

The Radical party (Personalistas) won the election of 1928, giving new strength to attempts at reform. The branch of the Radical party led by Yrigoyen controlled the Chamber of Deputies and was now very close to contesting the Conservative majority in the Senate. As a consequence, the Agricultural Committee proposed a new bill to the Chamber of Deputies changing and expanding some of the articles of Law 11,170; in practice, there had been many problems in enforcing this law because owners could easily avoid its strictures simply by renting plots larger than 300 hectares. The new bill proposed numerous changes (Table 6) ${ }^{57}$. These changes widened tenant farmers' rights by including all types of rural usages not simply cereal production, increasing contract terms, introducing the obligation of a written contract to avoid scams and limi-

54 See Rock, «Radical Populism».

55 See O'Connell, «Free Trade».

56 See Rock, «Radical Populism».

57 «...The danger of establishing the limits to the rented land area is that - since owners or intermediaries with bad intentions try to avoid the law - they rent land plots just above the 300 hectares limit». Deputy Roque Coulin from the UCR (Santa Fé) proposing the bill Chamber. HCD, September 18th, 1929, p. 593. 
ting subcontracting. Because of the renewed power of the Radicals in Congress, Deputies insisted on regulating all contracts in the country, not just in the Pampean region. In the case of subcontracting, Deputies wanted to prevent speculation on the part of firms which rented large land extensions to subdivide and sublet smaller plots to tenant farmers. They wanted to avoid the overpriced contracts these companies offered by banning such a practice. Law 11,170 failed to do so, since the extension limit plus the changes introduced by the Senate preserved the right to continue subcontracting practices. The new bill limited such a possibility to specific cases of death or injury of the renter ${ }^{58}$.

Most of the adjustments proposed by the Deputies were influenced by the desires of their rural constituencies, namely farmers and cattle ranchers. Nicolas Repetto explained the need to attend to these political demands and warned the Deputies about the dangers of failing to provide new legislation:

«The Deputies can relax for the moment, because there are a high proportion of foreigners among our producers. But the day will come when the children of these foreigners, the Argentineans, will want to mobilize and claim for themselves the share of the agricultural product that belongs to them. Then, on that day, if the legislation is not ready, some movement in the rural sector will remind those who govern that there is a great need to be satisfied» ${ }^{59}$.

However, the bill still had to go through Senate where Senators tried to avoid considering it at all. The Codes Committee received the bill from the Deputies on September 27th 1929 but did not pass a resolution during the Ordinary Session. By November 19th, the Executive Power sent notification to the Senate asking them to include the bill in the extended period for Ordinary Sessions, «...[The bill] has to pass immediately so the new agricultural year can begin in a position of a legally mandated atmosphere more humanitarian, fair and conducive to reducing the costs that nowadays burden National production» ${ }^{60}$.

Finally, on January 25th 1930, the Senate debated the bill and passed it with minor changes (Table 3). This time, the Conservatives were too

58 See debates in the Chamber of Deputies in 1920 and the Senate in 1921 where all the speculations about these subcontracting practices are debated and the preferences to legislate against these groups of firms are clearly expressed.

59 Deputy Nicolas Repetto (Socialista), from Cap. Federal, supporting the bill presented in the Chamber. HCD, September 18th, 1929, p. 595.

60 Message from the Executive Power to the Senate, November 19th, 1929. HCS, November 19th 1929, p. 735. 


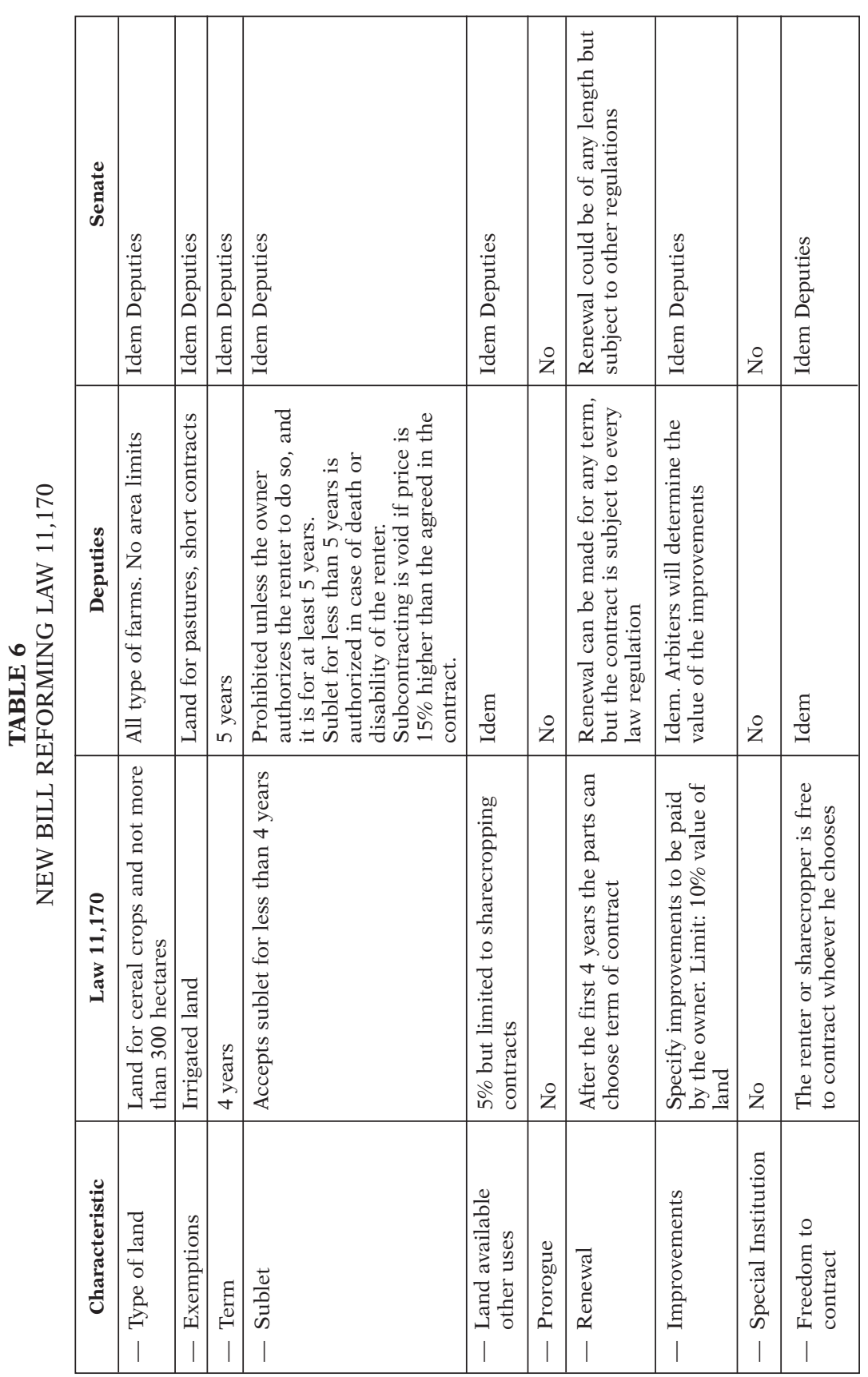




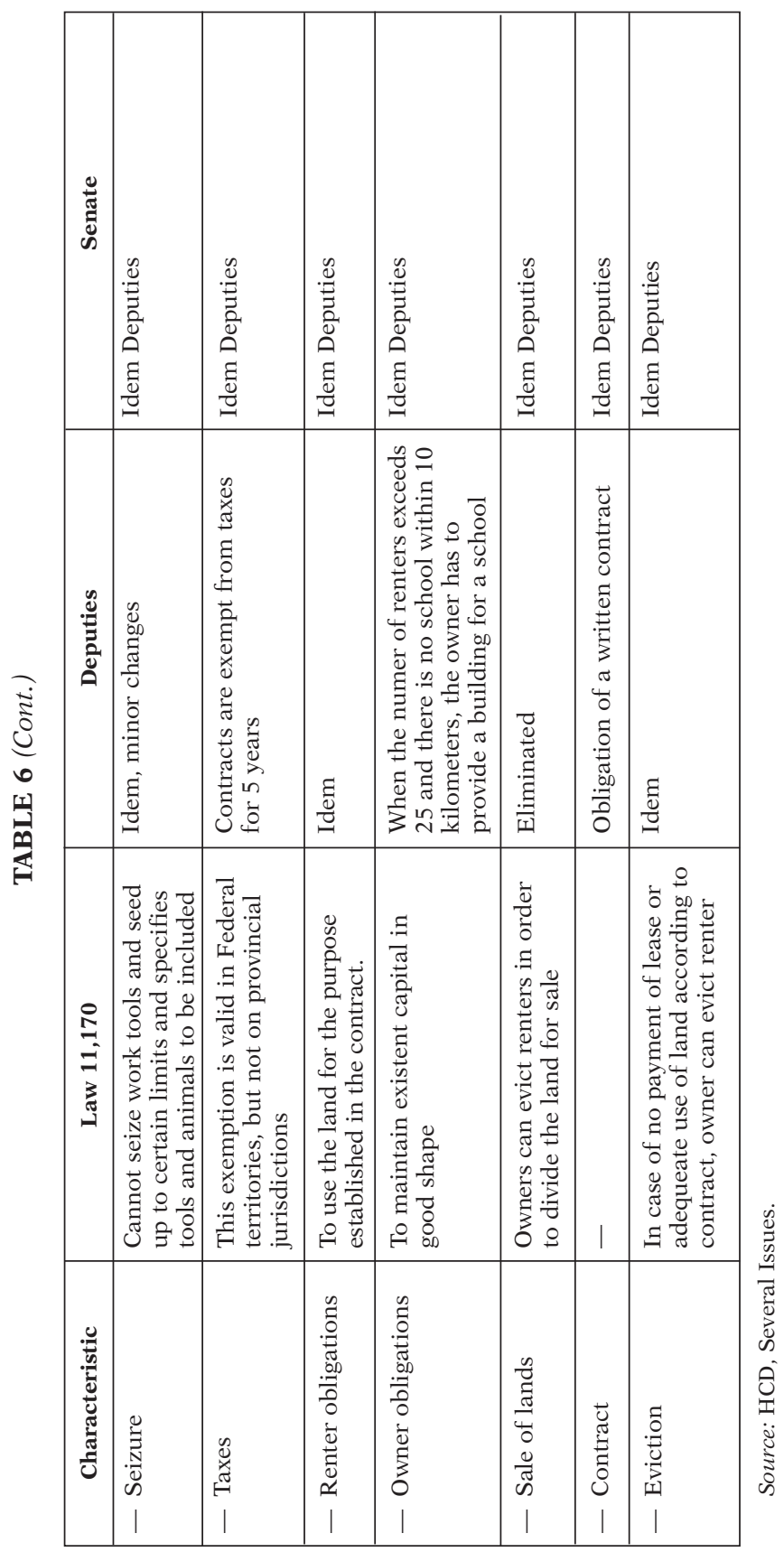


weak in the Senate to impose a series of changes similar to those of 1921. A bitter debate between Conservatives, Radicals and Socialists regarding the elimination of types of farms to be included and minimum plot size took place. Nonetheless, Radicals and Socialists were able to carry the reforms ${ }^{61}$. Some Conservatives who strongly opposed the law left the floor, disgusted with the resulting law and their inability to fight against it $^{62}$. The only change the Committee proposed was to let the parties freely decide contract terms after the first five-year contract.

Once the law had been passed by Senate, it returned to the Chamber of Deputies which, no doubt, would have accepted the minor changes proposed by the Senate. However, the military coup of 1930 suspended the activities of Congress, and the law could not be passed until 1932. The new Chamber of Deputies (elected in fraudulent elections and without the Radical party) approved the law as it came from the Senate Chamber. Conservatives in the Senate, notified of the new law in 1933, did not receive the new legislation well. They tried to have it declared unconstitutional but the law was already in place. Figure 1 shows the spatial distribution of the Deputies' and the Senators' preferences concerning the new law.

Spatial analysis of preferences was first introduced by Downs (1957) and later adopted by political scientists ${ }^{63}$. The horizontal line represents the political issues, with both extremes representing opposing views on a given topic. The vertical lines represent the preferred points for each political actor, and the distance between the lines indicates how far apart

FIGURE 1

POLITICAL EQUILIBRIUM 1929-32

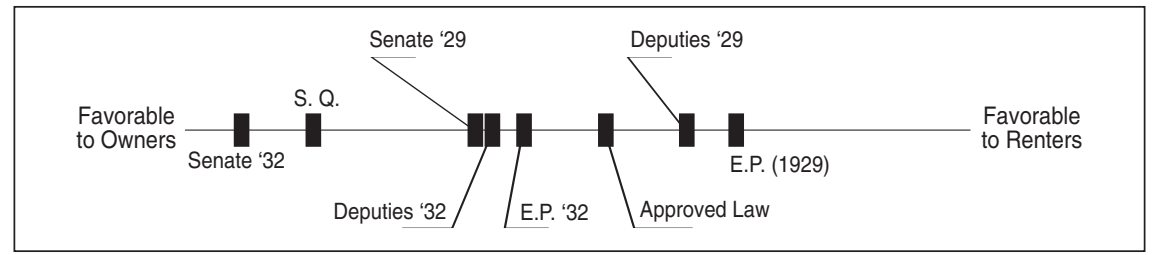

61 HCS, January 25th-28th 1930.

62 "I leave; I do not want to contribute myself to the sanction of a bad law», Senator Linares from Salta. HCS, January 28th 1930, Reunión 70 Continuation 7th prorogue Session, p. 353.

${ }^{63}$ See Poole and Rosenthal, «U.S. Presidential Elections»; Poole and Rosenthal "Analysis of Congressional Coalitions»; Koford, "Dimensions», and Poole and Rosenthal, "Spatial Model». 
their points of view are. The Status Quo (S.Q.) represents the current legislation, and the further a given actor, or political group, is from the Status Quo, the stronger its preference for changing the legislation. Spatial analysis is widely used in analyzing the ordering of preferences of political bodies like Congress or during elections ${ }^{64}$. It has also been used in economic history analysis ${ }^{65}$. In Figure 1, the Status Quo (S.Q.) represents Law 11,170 of 1921. Moving along the line to the right, contract regulations favor renters. Movements to the left indicate regulations favorable to owners. The Chamber of Deputies and the Executive Power (E.P.) held the strongest preferences for the new bill, consequently their preferred points are found to the right of the horizontal line. In 1928, the position of the Radical party strengthened in the Senate. Furthermore, the UCR Antipersonalistas, even though allied with the Conservatives, supported renters' legislation. Hence, we can see the Senate's preferred point was closer to the Deputies and the Executive than it had been in 1921. As a result, the bill extended renters' rights, removing the limits to the size of land plots and including the whole country, not just the Pampean region. After the military coup, the new Senate in 1932 moved closer to the Status Quo, which explains the attempt to nullify the law. Besides, the Chamber of Deputies and the Executive Power also moved toward the Status Quo, although still preferring to pass the renters' law. It is worth mentioning that President Justo, elected in 1932, came from the Radical Antipersonalistas and in the Chamber of Deputies Antipersonalistas, Socialists and Democratas Progresistas were able to defeat Conservatives, even though during the rest of the 1930s the Antipersonalistas formed a coalition with the Conservatives and Socialistas Independientes.

\section{THE LEGACY OF THE RADICAL GOVERNMENTS}

The Radical governments from 1916 to 1930 tried to introduce tenancy reform; their success was modest and even disappointing because of their own political disputes, but more importantly because of the role Conservatives played in Congress. Furthermore, as the previous analysis shows, the division between parties made the issue even more complex because of different policy preferences between the Pampean provinces and the provinces of the Interior. Nonetheless, tenancy legislation was passed when the Radicals controlled the Chamber of Deputies

${ }^{64}$ See Poole and Rosenthal, "Patterns»; Rosenthal, «Unidimensional Congress», and Alesina and Rosenthal, «Partisan Politics».

65 See Seltzer, "Political Economy». 
and under Yrigoyen's presidencies (Figure 2). Even though the Radical leadership was rooted in the same economic and social class as the Conservatives, the Radicals, by allowing democracy and political institutions to work, became more aware of their electorate's demands. This explains why Radical Deputies supported rural rent legislation. Furthermore, the democratic process allowed an evolution of legislation as errors in the early law were adjusted and amended by succeeding waves of reform.

Conservatives did not have popular support but they used their veto power in the Senate to block legislation contrary to landowners' interests. By 1930 Conservative influence in the Senate was declining and complete control of Congress by the Radicals would have opened the gates for further reform. However, the military coup of 1930 and the restoration of Conservatives to power eliminated the influence renters and farmers had enjoyed in Congress and delayed legislation, even delaying improved enforcement of existing laws.

Finally, enforcement of the new legislation was a more difficult issue for two main reasons. First, after Yrigoyen, the new Radical government had closer ties with the Conservatives even though they differed in many issues. Second, as studied by Palacio (2001), at the micro level, contracts were enforced by local judges who sympathized with landowners.

FIGURE 2

RADICAL PARTY STRENGTH IN DEPUTIES CHAMBER AND NUMBER OF BILLS INTRODUCED

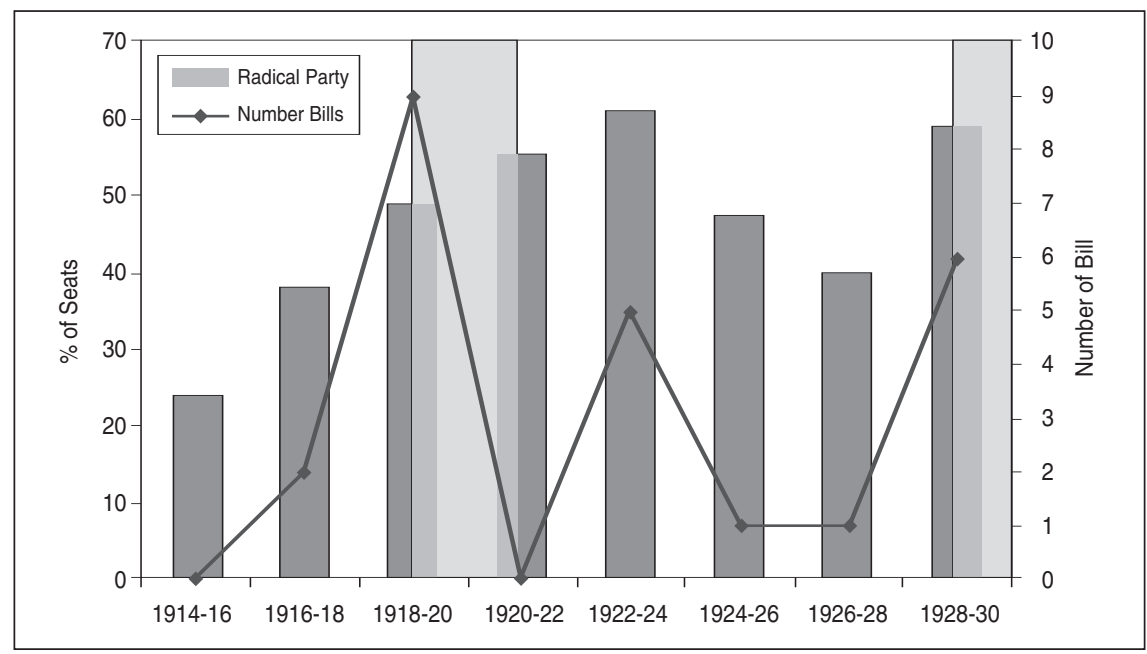

Source: Molinelli et al, 1999 and Cámara de Diputados several issues. 


\section{CONGRESS AND GOVERNMENT IN THE 1930S}

On September 6th 1930 a military coup overthrew Yrigoyen and established a military government ${ }^{66}$. Eighteen months later the military government called new elections banning the participation of officials from the Radical government ${ }^{67}$. During the 1930 s and early 1940 s, the country was controlled by a coalition of parties which resorted to fraud to hold office. This Conservative coalition, called Concordancia, was formed by the UCR Antipersonalistas, the Partido Demócrata Nacional and the Socialistas Independientes ${ }^{68}$. Fraud was perpetrated mainly to the detriment of the Radical party which had popular support ${ }^{69}$.

In the Chamber of Deputies the Concordancia kept enough seats to retain its majority (Table 7 ). Because of prohibitions and persecutions, the Radical party decided not to take part in elections from 1932 to 1934. However, from 1936 on, the Radicals returned and gained some seats despite the growing fraud. Finally, in the 1940 election, the government decided to adopt a more transparent system, as evidenced by the increase in seats for the Radical Party (Table 7) ${ }^{70}$.

During the 1930s, most of the members of the Agriculture Committee came from the Pampean region but the Conservatives held the majority of the seats. As the Radicals returned to engage in elections and the political system opened up again in 1940, most of the members of the Committee were from the Radical party ${ }^{71}$. In the Senate, the Conservatives had control during the 1930s but they lost some seats to the Radicals at the end of the 1930s and beginning of the 1940s (Table 7) ${ }^{72}$.

As a consequence, the Democrata Nacional party controlled the Senate during the first years, but needed their allies, Antipersonalistas and Socialistas Independientes, to maintain the majority afterwards. The Concordancia held a majority throughout the period, but reached its lowest level in the last two years when the Radicals passed the law on rural rents.

66 See Halperin Donghi, "Republica».

67 See Schillizzi Moreno, "Argentina».

68 See Aguinaga and Azaretto, "Decada».

69 See Alston and Gallo, "Erosion of Rule of Law», and Halperin Donghi, "Republic».

70 President Ortiz was convinced that the system should return to normality. He nullified the elections for Deputies and Governors in the province of Buenos Aires in 1940 because of the fraud, and called new elections. As a result, the Radical party easily won the election. See Halperin Donghi, "Republica».

71 See Halperin Donghi, «Republica».

72 See Canton, "Elecciones y Partidos Politicos». 
TABLE 7

CONGRESS COMPOSITION 1932-42

(Percentage of total seats)

\begin{tabular}{|c|c|c|c|c|c|c|}
\hline & \multicolumn{6}{|c|}{ Chamber of Deputies } \\
\hline & 1932 & 1934 & 1936 & 1938 & 1940 & 1942 \\
\hline UCR... & - & 1.3 & 25.6 & 40.8 & 48.1 & 40.6 \\
\hline 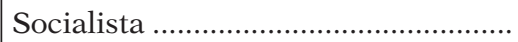 & 27.4 & 27.7 & 16.0 & 3.2 & 3.2 & 11.0 \\
\hline Demócrata Progresista ....................... & 8.9 & 7.7 & 3.8 & - & - & - \\
\hline UCR Antipersonalista ........................ & 10.8 & 10.3 & 7.1 & 3.2 & 4.4 & 12.3 \\
\hline UCR Unificada ............ & 2.5 & 2.6 & 2.6 & 3.2 & 3.2 & 1.3 \\
\hline Socialista Independiente .................. & 7.0 & 3.9 & 1.3 & - & - & - \\
\hline 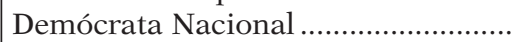 & 35.7 & 38.7 & 35.3 & 37.6 & 31.0 & 31.0 \\
\hline Liberal........................... & 3.2 & 2.6 & 1.3 & 0.6 & - & - \\
\hline 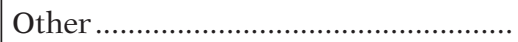 & 4.5 & 5.2 & 7.1 & 11.5 & 10.1 & 3.9 \\
\hline Total .... & 100.0 & 100.0 & 100.0 & 100.0 & 100.0 & 100.0 \\
\hline \multirow[t]{3}{*}{ Concordancia ......................................... } & 53.5 & 52.9 & 43.6 & 40.8 & 35.4 & 43.2 \\
\hline & \multicolumn{6}{|c|}{ Senate } \\
\hline & 1932-34 & \multicolumn{2}{|c|}{ 1935-37 } & \multicolumn{2}{|c|}{$1938-40$} & $1941-43$ \\
\hline Demócrata Nacional.. & \multirow{7}{*}{$\begin{array}{r}50.0 \\
6.7 \\
23.3 \\
3.3 \\
3.3 \\
6.7 \\
6.7\end{array}$} & \multirow{2}{*}{\multicolumn{2}{|c|}{$\begin{array}{r}43.3 \\
6.7\end{array}$}} & \multicolumn{2}{|c|}{40.7} & 34.6 \\
\hline 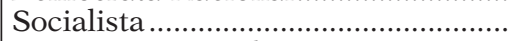 & & & & \multirow{2}{*}{\multicolumn{2}{|c|}{7.4}} & 7.7 \\
\hline UCR Antipersonalista ......................... & & & 30.0 & & 22.2 & 23.1 \\
\hline 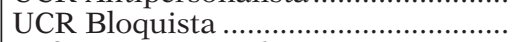 & & & 3.3 & \multicolumn{2}{|c|}{3.7} & - \\
\hline Defensa Provincial. & & & 3.3 & \multicolumn{2}{|c|}{-} & - \\
\hline Popular..................... & & & 6.7 & \multicolumn{2}{|c|}{3.7} & - \\
\hline Democrata Progresista ......... & & & 3.3 & \multicolumn{2}{|c|}{3.7} & 7.7 \\
\hline Socialista Independiente..... & - & & 3.3 & \multirow{2}{*}{\multicolumn{2}{|c|}{$1 \overline{8.5}$}} & - \\
\hline 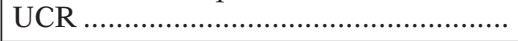 & 一 & & - & & & 23.1 \\
\hline 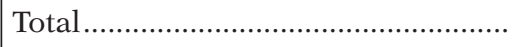 & 100.0 & & 100.0 & 100.0 & & 96.2 \\
\hline Concordancia ...................................... & 73.3 & & 76.7 & 63.0 & & 57.7 \\
\hline
\end{tabular}

Note: Concordancia is the sum of Demócrata Nacional, Socialista Independiente and UCR Antipersonalista.

Source: Molinelli, 1999.

\section{REFORMS UNDER CONSERVATIVE RULE (1932-1943)}

During the Conservative restoration of the 1930s, the government had to face two crises in international markets which affected the rural sector and the economy as a whole ${ }^{73}$. First, during the Great Depression,

73 See Diaz Alejandro, "Essays»; Alhadeff, «Economic Formulae», and della Paolera and Taylor, "Straining the Anchor». 
the government of General Agustin Pedro Justo sought to regulate rent prices to help farmers survive the crisis. The second reform came during the Second World War when, in response to the sudden closure of most export markets in Europe to Argentine farmers, emergency measures for tenants were provided by the Executive Power through Decrees. Nonetheless, the Radicals, with a majority in the Chamber of Deputies, sought to introduce new and long-lasting reforms to tenancy legislation. Thus it may be seen that the main proposals for tenancy regulation had their roots in severe economic crises.

During the first years of the government of President Justo, legislation presented in Congress had two main objectives. The first was to help the country, especially the battered rural sector, overcome the crisis in international markets ${ }^{74}$. Among other measures, the government resorted to bilateral negotiations with Great Britain to sustain rural exports, created a Regulatory Board to maintain reasonable crop prices and engaged in import substitution in order to help the economy recover ${ }^{75}$. Second, the government, especially those politicians related to the Radicals Antipersonalistas, tried to win over the traditional electorate of the Radicals. As a result, there was a high level of activity in Congress during the first two years of the new government but results were insignificant, and tenancy legislation had to wait until the Radicals regained a majority in the Chamber of Deputies.

\subsection{Legislation in the early Conservative government}

The most important piece of legislation introduced in the early 1930 s was a bill to renegotiate rent prices. On April 5th 1932 the Executive Power formed a Committee representing different rural institutions to propose a series of bills to support and improve the rural sector ${ }^{76}$. The Committee consisted of several institutions which represented diverse interests in the rural sector, the banking sector, and representatives of the Ministry of Agriculture (HCD, 1932). Following the Committee's advice, the Executive Power sent a bill to Congress. The government took into consideration the fact that rural rents had been adjusted privately, but the decline in international prices for rural products was bigger than the actual rent reduction ${ }^{77}$. The bill provided for the creation of

${ }^{74}$ See Díaz Alejandro, "Essays»; Balsa, "Crisis de 1930», and Botana et al., "Crisis de $1930 »$.

75 See Díaz Alejandro, "Essays», and Pereyra, "Tiempos de la republica agropecuaria».

${ }^{76}$ HCD, May 31st, 1933, Reunión 9, p. 322.

${ }^{77} I d$. 
mixed commissions for price settlement according to rural products' market prices, land yield and production cost in each region ${ }^{78}$.

In Congress, the most important political allies of the President were the Antipersonalistas, who had presented a similar bill a few months earlier. In September 1933, the Chamber passed the bill with important differences to the proposal of the Executive Power. These changes were a reflection of the influence of the Conservatives on the Chamber, who refused to accept an extreme bill favoring the rural renters since the coalition between Conservatives and big owners continued as strong as ever ${ }^{79}$. However, even with the changes introduced by Deputies, the Senate never debated this bill and so it died in Congress. The spatial analysis of preferences of each actor can be seen in Figure 3.

In this case, there is a new dimension in the policy spectrum of rural rents; that of price control. The horizontal axis represents the regulation dimension for contract clauses as explained before. The vertical axis represents preferences on price regulation. Therefore, as we move north in the graph, higher price control is desired. The dark points represent the preferred combination of price control and contract regulations for each actor, while the distance from the Status Quo shows level of disagreement with the current legislation. The circles centered on the preferred point for each actor and crossing the Status Quo are the indifference curves for each actor. Each political group will prefer any point insi-

FIGURE 3

POLITICAL EQUILIBRIUM 1933

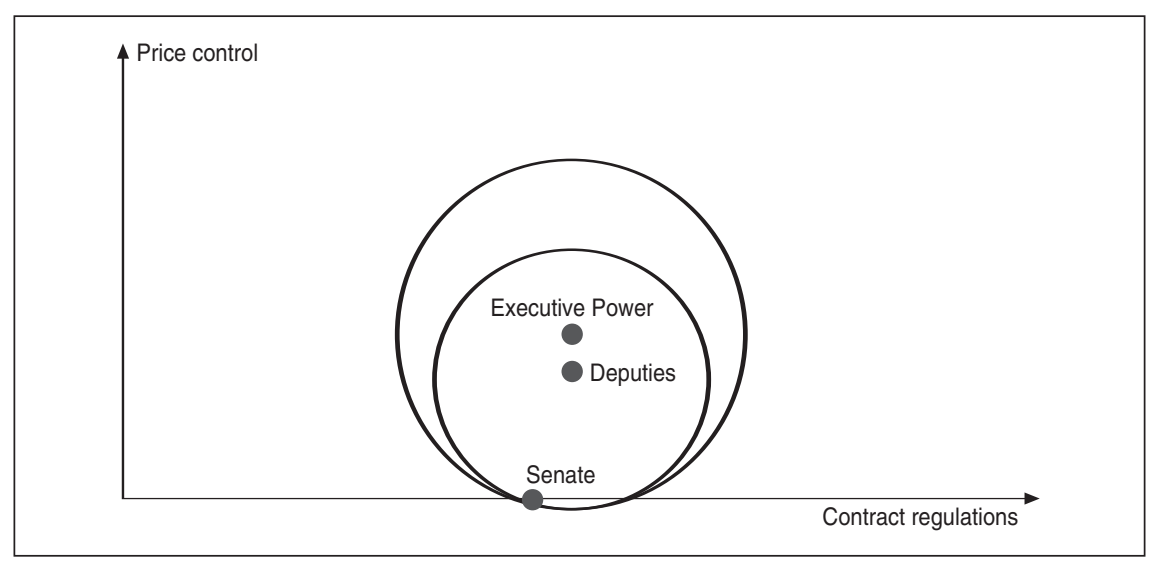

${ }^{78} \mathrm{Id}$.

79 See Ciria, "Partidos y Poder». 
de this circle to the Status Quo, since the distance from any point inside the circle to the preferred point is shorter than the distance from the Status Quo to the preferred point. The law discussed in 1929-1930, which regulated some aspects of the contracts but said nothing about prices, represents the Status Quo. The Executive Power wanted the price controls as an emergency measure because of the Great Depression and felt that price controls would be in line with similar regulations in other areas of the economy. Accordingly, its preferred point is above the Status Quo, given that the new bill did not propose changes to contract regulations. It is interesting to notice that in this proposal the emphasis of the reform shifted from contract regulations to price control, constituting the first serious attempt to introduce rent price controls. Nonetheless, the Chamber of Deputies did not agree on most of the reforms proposed by the Executive and reduced the number of changes. Therefore, the preferred point for the Chamber of Deputies was above the Status Quo but below the preferred point for the Executive. As a result, the bill passed the Chamber of Deputies with many reforms. However, the Senate's preferred point, because of the Conservative majority, was the Status Quo; that is, they did not want $t$ regulate prices. This explains why the Senate never debated this bill.

\subsection{The reform of $1940-1942$}

The tenancy reform of 1941-1942 was significantly different from the previous two laws. First, the crisis in the international cereal markets created by the World War was even more serious than the Great Depression ${ }^{80}$. Most of the European markets for Argentine products were closed and prices dropped sharply. In response, the Executive Power dictated an emergency decree establishing a mechanism to tie rural rent prices to the decline of international prices. Second, legislators were pushing for broader reforms of rent prices and contract extensions. Third, the Conservatives, especially the Executive Power, were forced by the crisis to offer a real solution to the rural problem ${ }^{81}$. Fourth, the Radicals, both the UCR and the UCR Antipersonalista, because of their majority in the Chamber of Deputies coupled with the situation caused by the deep economic crisis, could now get what they had only been able to propose before —improved conditions for renters.

\footnotetext{
80 See Díaz Alejandro, «Essays».

${ }^{81}$ The same system of price controls during the wars was applied in England (Offer, 1991).
} 
The roll call in Congress illustrates Deputies' preferences ${ }^{82}$. On September 9th 1941, the Conservatives tried to stop or delay this bill. Deputies from the Conservative coalition voted against considering the law. Meanwhile, Radicals, Socialistas and some of the Radicals' Antipersonalistas voted to debate the bill immediately. It is worth noting that some Radicals switched and voted with the Conservatives. It is also interesting that most of the Deputies who voted for an immediate debate came from the Pampean region. Therefore, as in previous cases, Congress was divided along party lines (Conservatives and their allies versus Radicals and their allies) and along regional lines (Pampean region versus the rest of the country). Econometric analysis of the rollcall vote shows this division between party and regional lines (Table 8).

TABLE 8

LOGISTIC REGRESSION DEPUTIES' CHAMBER POSTPONES RURAL RENTERS' BILL

(Dependent variable: Postpone: $1=$ Yes, $0=$ No)

\begin{tabular}{|c|c|c|c|c|}
\hline \multirow[b]{2}{*}{ Variable } & \multicolumn{2}{|c|}{ Model 1} & \multicolumn{2}{|c|}{ Model 2} \\
\hline & Coefficient & Std. Error & Coefficient & Std. Error \\
\hline Radical.. & -5.393 & $1.3618(* * *)$ & - & - \\
\hline Socialista Antipersonalistas ..... & -3.588 & $1.4443(* *)$ & - & - \\
\hline 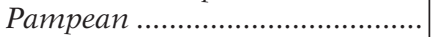 & - & 1.2216 & -1.180 & \\
\hline Región........................................... & 1.102 & - & - & $0.5205(* *)$ \\
\hline Seniority $\ldots \ldots \ldots \ldots \ldots \ldots \ldots \ldots \ldots \ldots \ldots$ & -0.006 & 0.1272 & - & - \\
\hline 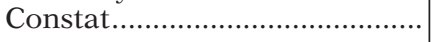 & 2.962 & $1.2178(* *)$ & 0.762 & $0.4577(*)$ \\
\hline $\begin{array}{l}\text { Pseudo R } 2: 0.4599 \\
\text { Predictability: } 86.21 \% \\
\text { Log Likelihood: }-32.545 \\
\text { Observations: } 90 \\
(* * *) \text { Significative 1\%, } \text { (**) Signifi }^{(* 2)}\end{array}$ & \multicolumn{4}{|c|}{$\begin{array}{l}\text { Pseudo } \mathrm{R}^{2}: 0.041 \\
\text { Predictability: } 62.22 \% \\
\text { Log Likelihood: }-59.443 \\
\text { Observations: } 90\end{array}$} \\
\hline
\end{tabular}

\begin{tabular}{|c|c|c|c|}
\hline \multicolumn{4}{|c|}{ Logistic Model for Vote (Model 1) } \\
\hline & & \multicolumn{2}{|c|}{ True Result } \\
\hline & & $\begin{array}{c}\text { Positive } \\
\text { T }\end{array}$ & $\begin{array}{c}\text { Negative } \\
T\end{array}$ \\
\hline \multirow{2}{*}{ 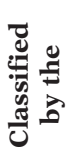 } & $\begin{array}{c}\text { Positive } \\
\text { M }\end{array}$ & 31 & 1 \\
\hline & $\begin{array}{c}\text { Negative } \\
\text { M }\end{array}$ & 11 & 44 \\
\hline
\end{tabular}

\begin{tabular}{|c|c|c|c|}
\hline \multicolumn{4}{|c|}{ Logistic Model for Vote (Model 2) } \\
\hline & & \multicolumn{2}{|c|}{ True Result } \\
\hline & & $\begin{array}{c}\text { Positive } \\
\text { T }\end{array}$ & $\begin{array}{c}\text { Negative } \\
\text { T }\end{array}$ \\
\hline \multirow{2}{*}{ 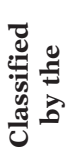 } & $\begin{array}{c}\text { Positive } \\
\text { M }\end{array}$ & 15 & 7 \\
\hline & $\underset{M}{\text { Negative }}$ & 27 & 41 \\
\hline
\end{tabular}

82 See Seltzer, "Political Economy». 
The dependent variable is the vote on delaying the debate of the bill. The independent variables are the Radical Party (Radical), Socialistas (Socialist), UCR Antipersonalista (Antipersonalistas), Deputies from the Pampean Region (Pampean Region) and Deputies' seniority (Seniority) ${ }^{83}$. In the first model we included all the variables, showing that the coalition of Radicals, Socialistas and Antipersonalistas rejected the proposal of delay. Seniority and regional differences were not significant. If we only consider regional differences (Model 2), we can see that Deputies from the Pampean region were against postponing debate on the bill.

Model 1 has a high level of predictability, 86.2 per cent. As a result, Radicals, Socialistas and, to some extent, Antipersonalistas, favored tenant farmers, while Democratas Nacionales and other smaller Conservative parties aligned with owners. Furthermore, we can see that some regional differences existed, with those Deputies from the Pampean region being more akin to renters' preferences.

Given the urgency of the situation, the Executive Power issued two Decrees establishing the institutions to renegotiate rent prices ${ }^{84}$. The decrees created a centralized Arbitrage Committee in charge of the system. This Committee had to name local Committees which had the authority to arbitrate between renters and owners. Price adjustment was not compulsory and once agreed upon by all parties, the new price would continue in force as long as the markets were in crisis ${ }^{85}$. Radicals presented several bills containing most of the clauses contained in the Executive decrees (Table 9). However, they had to deal with the Conservatives who still dominated the Senate. The Executive Power sent a bill on which complemented the previously established decree (Table 9). The Chamber of Deputies introduced important changes to the bill, the most important being the limitation of the law to rural production of cereals, i.e. to the Pampean region. This change was similar to the one that allowed the approval of Law 11,170 in the Senate in 1921. Besides, the bill excluded those contracts on mixed crop production, cattle raising and breeding, making the bill more acceptable to Conservative groups from the Pampas. On the other hand, it gave more rights to the renter than the original bill from the Executive Power, such as penalties and automatic adjustment of rent prices. The Radicals brought the proposal to create Arbitrage Boards back to the table. This proposal was supported by the Committee created by the Executive Power in 1933 and

83 The Pampean region included the provinces of Buenos Aires, Santa Fe, Entre Rios, Cordoba, and Capital Federal.

${ }^{84}$ See Blasco, "Arrendamientos y Aparcerias Rurales».

85 See Blasco, "Arrendamientos y Aparcerias Rurales». 
was included in the bill the Executive Power sent to the Congress. Despite the important changes proposed in the bill, the idea behind it was that fixing prices would be a transitory requirement to overcome the market crisis:

«All the solutions proposed —inside and outside of Congress- are in agreement that the rural renter's pricing problem is transitory and is caused by the difference between domestic and export product prices that has resulted from the war-time closing of foreign markets to such products. Then, given that the problem is transitory, the remedy is an emergency one and carries with it the conviction that once the grave situation has passed, the remedy will be no longer needed ${ }^{86}$.

The Chamber of Deputies passed the bill which went to the Senate and was passed with certain reforms (Table 9). Finally, the law was approved on September 23rd 1942.

The preferences of the different actors played a key role in deciding the final characteristics of the law (Figure 4).

The Executive Power and Chamber of Deputies also preferred an increase in the number of controls in rural rent contracts, such as the

FIGURE 4

POLITICAL EQUILIBRIUM 1942

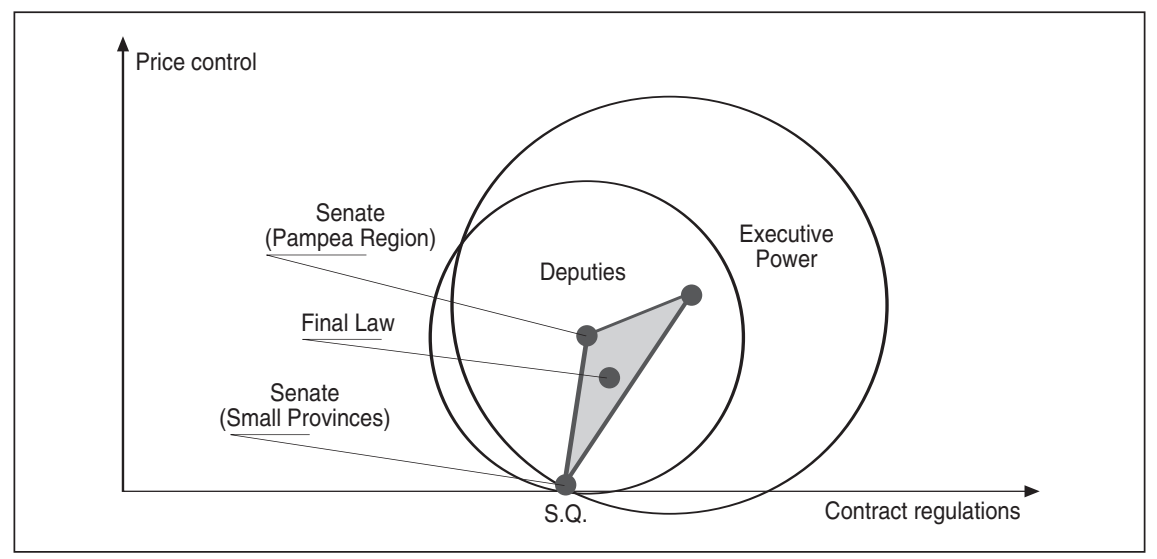

86 Deputy Mario Guido, (UCR) from the Province of Buenos Aires, when he presented the bill in the Chamber. HCD, September 2nd, 1941, p. 744. 


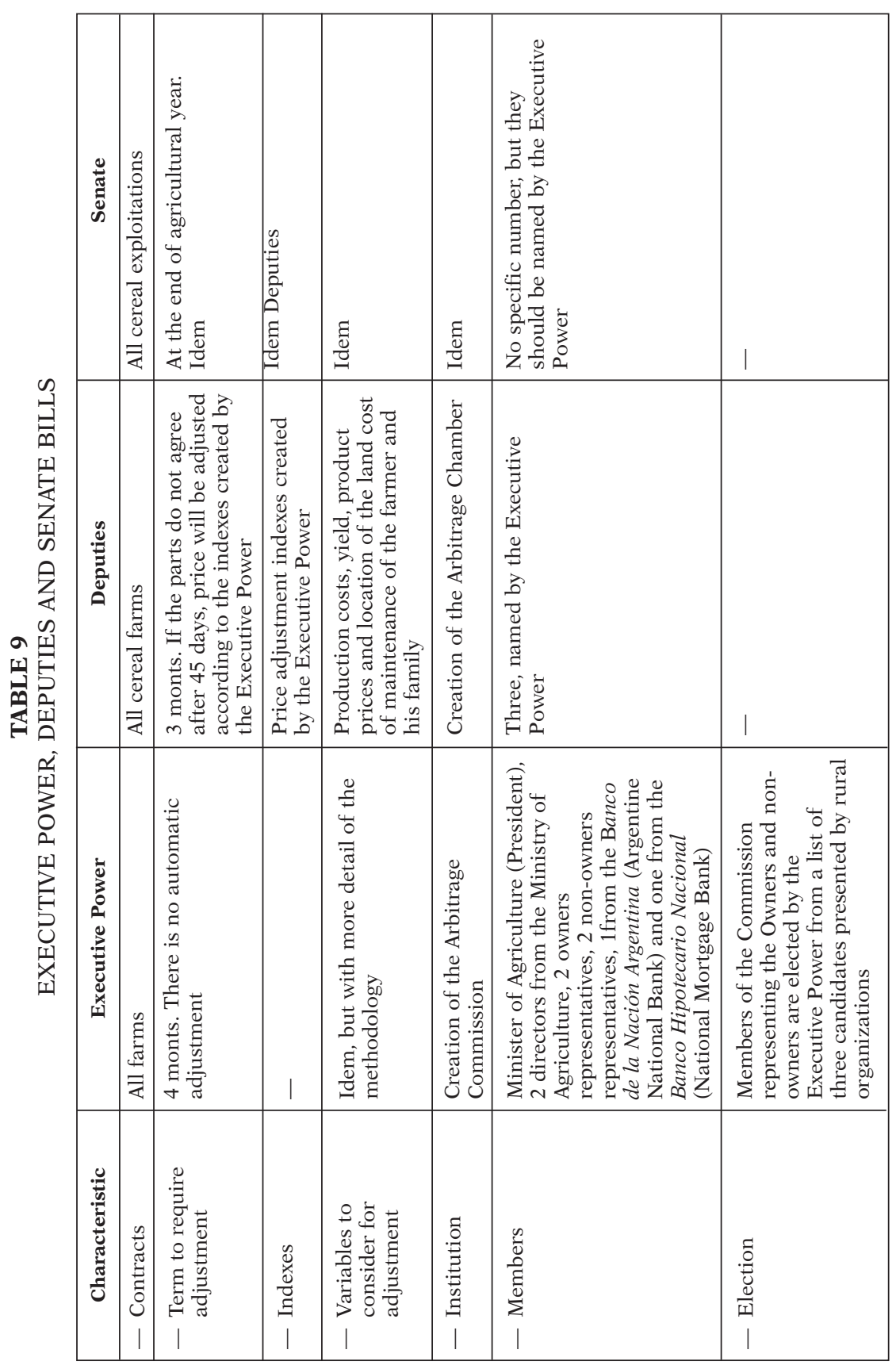




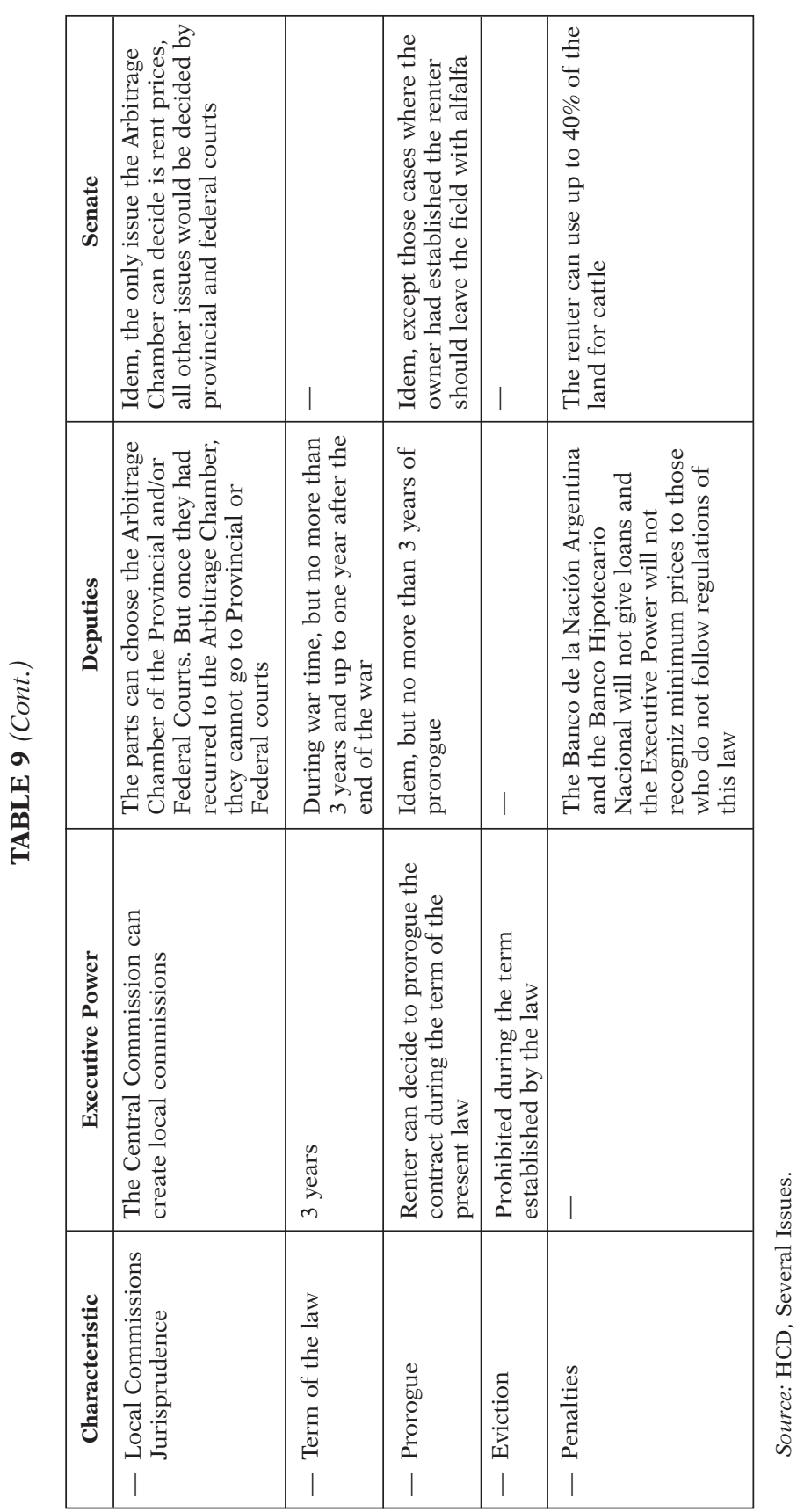


extension of contract terms. Nonetheless, the Chamber of Deputies wanted fewer controls because of the need to pass the law and convince the Conservatives in the Senate, especially those from small provinces, who preferred the Status Quo. Radicals and other Senators from the Pampean region preferred a solution similar to the one offered by the Chamber of Deputies. Therefore, as in the 1920-1921 reform, the Chamber of Deputies created the right incentives for Conservatives to pass the law. They limited the law to cereal production, leaving provinces outside the Pampean region unaffected. In the Senate, Radicals allowed contract flexibility for cattle raisers in the Pampas who were connected to Conservatives. In this reform process we can see again the tension which cut across parties, that is, Radicals and Conservatives, and across regions, that is, the Pampas and the interior of the country. It is interesting to notice that this pattern existed under democracy and under fraud, and defined Argentine politics for more than thirty years. Furthermore, during this period, Congress institutions provided the environment to foster compromises in legislation. The shadowed area formed by the combination of preferences of the Senate, the Executive Power and the Chamber of Deputies is the Pareto Optimal set for policy reform ${ }^{87}$. This area represents all the points in which the Chamber of Deputies, most of the Senate and the Executive Power could reach an agreement which increased everybody's welfare. It is interesting to notice how preferences changed from the reform in 1933. In this case, there is an increasing shift in the preferences of the Executive and the Chamber of Deputies to control rents and to introduce further regulations on rent contracts. In contrast to the 1933 bill, this piece of legislation was passed, but in the end it was not applied s the military Coup of 1943 nullified it by a decree, starting a series of dramatic changes for rural rents in Argentina. Nonetheless, this analysis shows how, from 1920 to 1942, preferences in Congress moved towards increasing the level of rent control and contract regulations.

\section{ECONOMIC EFFECTS OF TENANCY REFORM}

During this period, tenancy reform was not as effective in promoting sweeping changes in the performance of the agriculture sector and tenancy contracts. The first reason was that reforms were not as dramatic as the debate in Congress appeared to suggest ${ }^{88}$. Second, even though some of these reforms were important, the enforcement of the law was

\footnotetext{
87 See Seltzer, "Political Economy».

88 See Palacio, "La estancia Mixta», and Palacio, "La paz del trigo».
} 
weak. This allowed many owners to avoid the regulations of the law ${ }^{89}$. Nonetheless, we can detect some changes in land prices and rents after the introduction of these laws, especially after the 1932 legislation ${ }^{90}$. In the province of Buenos Aires, land prices increased as a consequence of the booming exporting sector, although the First World War and the Great Depression had a negative impact on real land values (Figure 5). In the First World War and its subsequent recession, land prices fell by 45 per cent from 1912 to 1920 , while from 1931 to 1934 land prices fell by 37 per cent.

The evolution of land prices closely followed that of the Rural Sector GDP (Figure 6). Nonetheless, we can observe a disconnection between the GDP of the rural sector and land prices after the Great Depression (Figure 6). This cannot be attributed to the passing of the second tenancy law since there were other measures implemented by the government during this period ${ }^{91}$.

FIGURE 5

LAND PRICES PROVINCE OF BUENOS AIRES

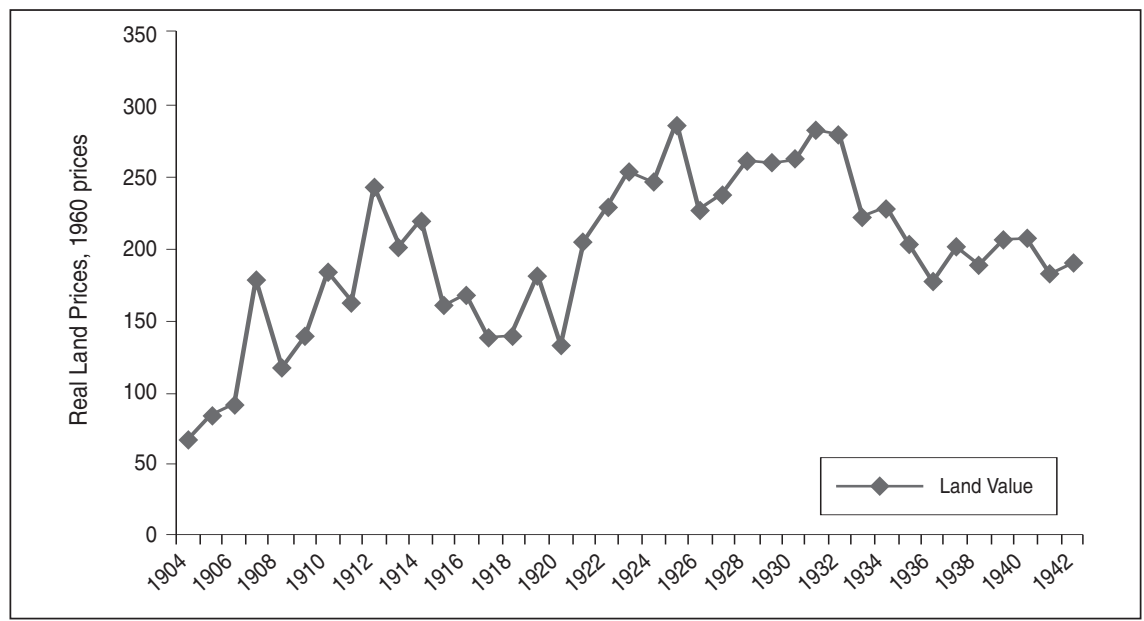

Source: Own elaboration based on Anuario Agropecuario de la Nación Argentina and Boletin Estadistico de la Provincia de Buenos Aires.

89 See Palacio, "La paz, del trigo».

90 Availability of land prices for the period of study corresponds to the province of Buenos Aires.

91 See, Díaz Alejandro, «Essays»; Di Tella and Zimelman, «Ciclos economicos»; Della Paolera and Taylor, «Straining», and Della Paolera and Taylor, "Economic Recovery». 


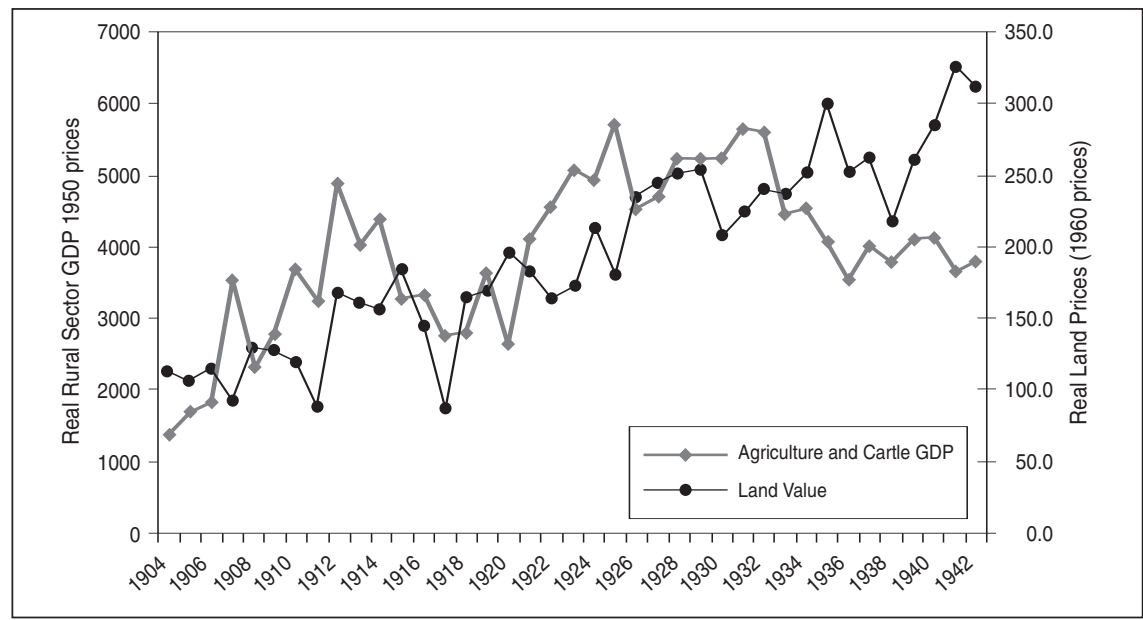

Source: Own elaboration based on Anuario Agropecuario de la Nación Argentina, Boletin Estadistico de la Provincia de Buenos Aires and CEPAL, 1958.

Nonetheless, the evolution of land prices with respect to those of beef and main crops followed a similar pattern (Figure 7). The ratio of land prices with respect to beef, maize and wheat suffered a major setback during the First World War and the Great Depression, recovering vigorously in the 1920s. In the 1930s, the sharp decrease in land prices with respect to rural prices was maintained with low levels throughout the decade (Figure 7 ).

The decline in land prices with respect to rural products in the 1930s was not simply an indication of the international economic conditions but also reflected changes in the domestic functioning of markets. As Figure 7 shows, there was a high correlation between land prices and beef prices before the 1930s, but subsequently this correlation is much weaker ${ }^{92}$.

With respect to the relationship between rent prices and land prices there are three main results. First, land prices fared better than rent prices during the Great Depression (Figure 9). From 1929 to 1933 rent prices declined by 40 per cent, while the decline in land prices was 14 per cent. Since land continued to decline, rent prices should also have decli-

92 The actual correlation after 1930 is negative. The same dissociation between prices is observed for the case of wheat, maize and flaxseed. 
FIGURE 7

RATIO OF LAND PRICES AND RURAL SECTOR PRICES

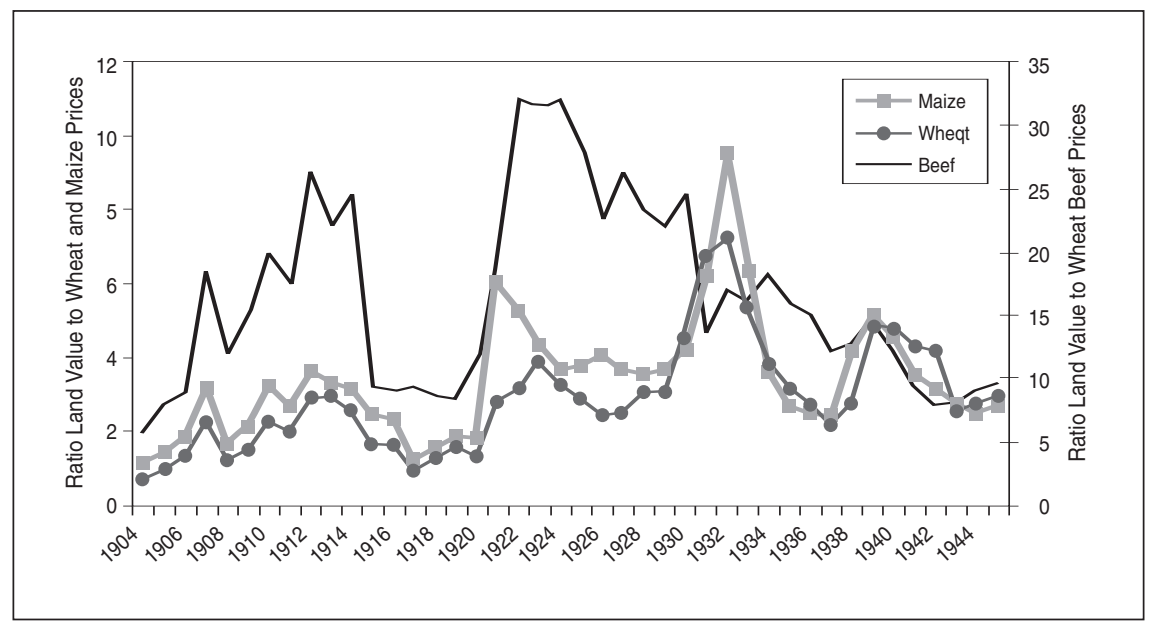

Source: Own elaboration based on Anuario Agropecuario de la Nación Argentina and Boletin Estadistico de la Provincia de Buenos Aires.

ned after $1933^{93}$. From 1929 to 1941 , the total decline in land prices was 19 per cent while that of rent prices amounted to 27 per cent. The strong decline in rent prices could have been an effect of the legislation on rents which, by forcing contracts to be at least five years in duration, did not allow for adjustment in rent prices. On the other hand, the international recession and lower exports could also have had an impact on rent prices.

Second, after 1929 there is a tendency for owners in the Pampean region to shift toward rent contracts paid as a percentage of the crop instead of cash contracts. In the rest of the provinces the tendency is to shift toward cash contracts instead (Table 10). This change in the structure of contracts could have resulted from two factors. On one hand, the more volatile international conditions could have increased the benefits of having a contract priced as a percentage of a crop since it would have minimized the effects of crop's price volatility on rent payments. On the other hand, contracts by percentage allowed owners to deal with inflation more effectively, given that the law established that contracts should be signed for at least five years.

93 Data for the years 1934-38 were not found. 
FIGURE 8

LAND PRICES AND BEEF PRICES

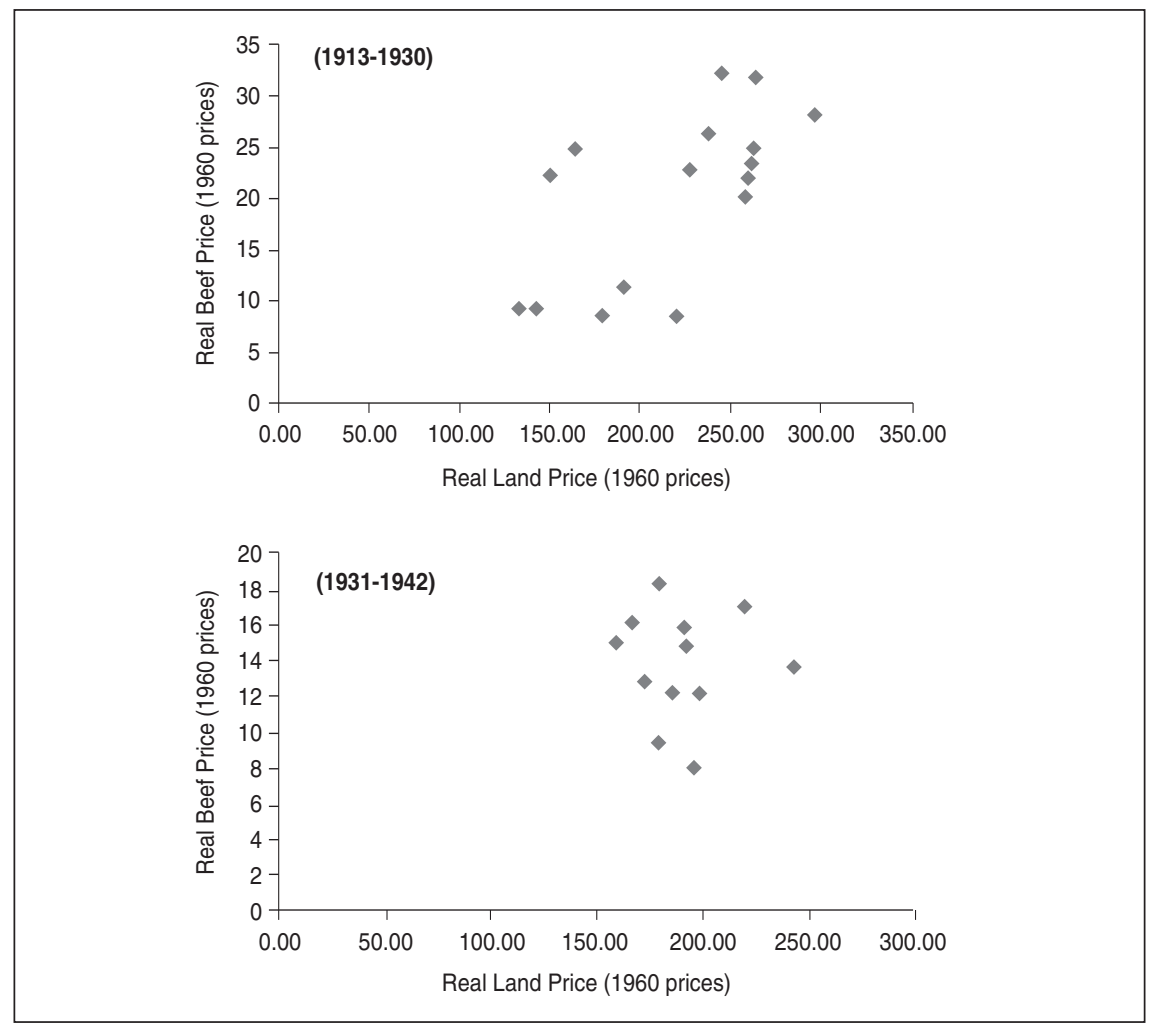

Source: Own elaboration based on Anuario Agropecuario de la Nación Argentina and Boletin Estadistico de la Provincia de Buenos Aires.

Finally, a higher percentage of renters with legal contracts is correlated with a lower rent price per hectare (Figure 10). This could be an indication that the regulation of the law provided lower prices for renters as the law required a minimum contract term of five years. This evidence is also correlated with the previous evidence of the switch toward contracts with share rents. Furthermore, the data show that a higher percentage of renters with a legal contract was not strongly correlated with the price share on the contract (Figure 11). As a result, there is some evidence supporting the claim that the law increased the advantage of using share contracts and depressed cash rent prices. These data suggest that legislation could have had an impact on contractual decisions even though the general market forces continued to rule contracts. 
FIGURE 9

LAND AND RENT PRICES

(Real Values 1960)

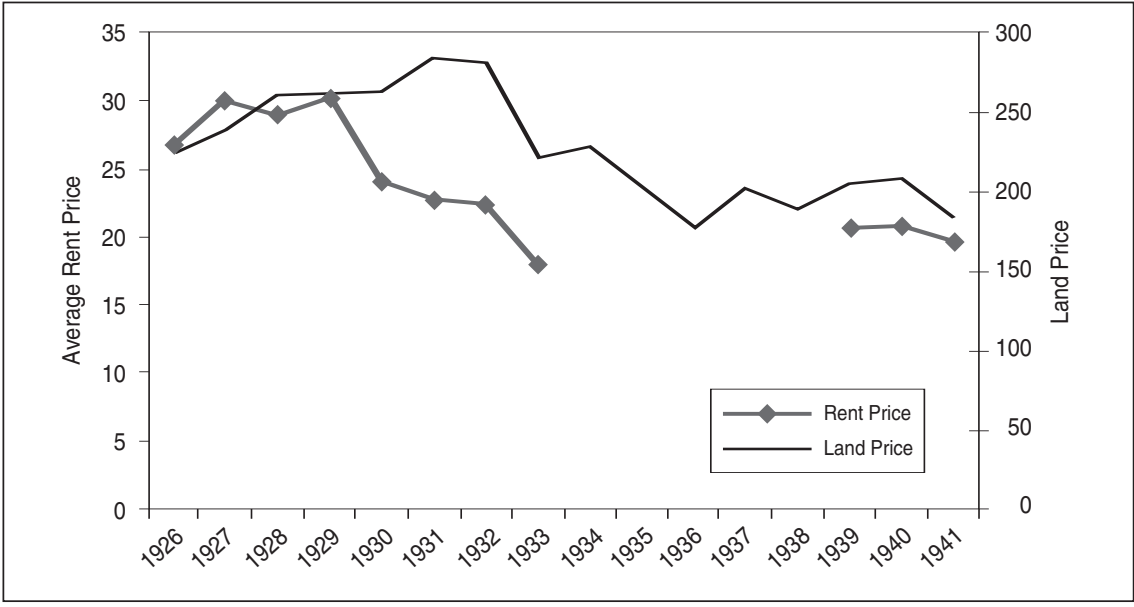

Source: Own elaboration based on Anuario Agropecuario de la Nación Argentina and Boletin Estadistico de la Provincia de Buenos Aires.

FIGURE 10

CONTRACTS AND PRICE OF RENT

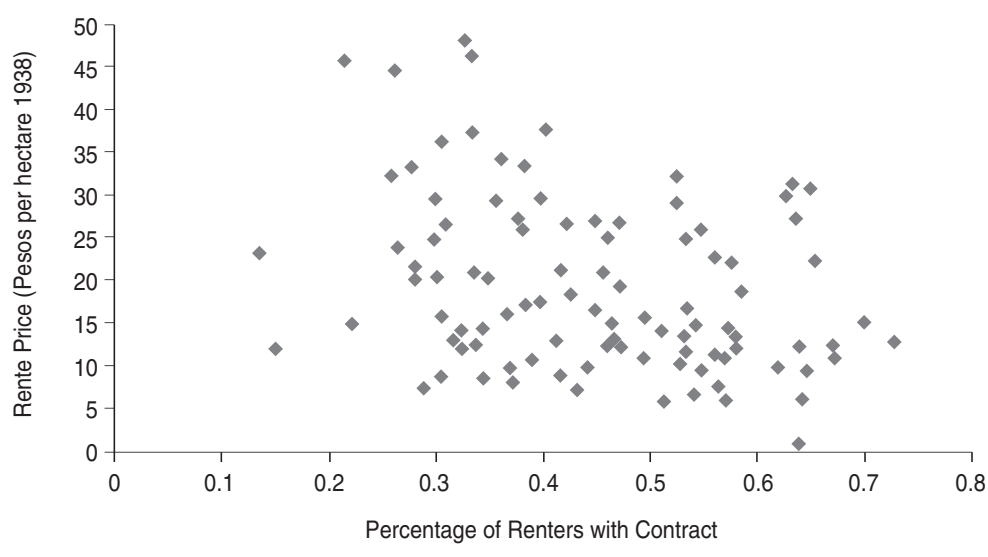

Source: Own elaboration based Boletin Estadistico de la Provincia de Buenos Aires. 
TABLE 10

NUMBER OF FARMS AND TENANCY

Cereals and Flaxseed (except Maize)

\begin{tabular}{|c|c|c|c|c|c|c|}
\hline \multirow{2}{*}{ Country } & \multirow{2}{*}{ Total } & \multirow{2}{*}{ Owners } & \multicolumn{2}{|c|}{ Renters } & \multirow{2}{*}{$\begin{array}{l}\text { Share- } \\
\text { croppers }\end{array}$} & \multirow{2}{*}{$\begin{array}{l}\text { Percentage of } \\
\text { Contracts as \% }\end{array}$} \\
\hline & & & Cash & Share & & \\
\hline \multicolumn{7}{|l|}{ Totals } \\
\hline $1929 \ldots \ldots \ldots \ldots \ldots \ldots \ldots$ & 152,281 & 58,852 & 38,178 & 50,179 & 5,072 & - \\
\hline $1932 \ldots \ldots \ldots \ldots \ldots \ldots \ldots \ldots \ldots \ldots \ldots$ & 133,447 & 48,790 & 30,474 & 49,487 & 4,696 & - \\
\hline $1933 \ldots \ldots \ldots \ldots \ldots \ldots \ldots$ & 135,800 & 49,185 & 27,808 & 54,391 & 4,416 & - \\
\hline \multicolumn{7}{|l|}{ Buenos Aires } \\
\hline .............. & 49,023 & 18,676 & 19,771 & 9,607 & 969 & 19.6 \\
\hline 1932. & 52,346 & 18,672 & 18,393 & 13,931 & 1,350 & 26.6 \\
\hline $1933 \ldots$ & 55,120 & 18,035 & 17,642 & 18,140 & 1,303 & 32.9 \\
\hline \multicolumn{7}{|l|}{ Santa Fe } \\
\hline $1929 \ldots \ldots \ldots \ldots \ldots \ldots \ldots$ & 43,650 & 16,203 & 8,994 & 16,791 & 1,662 & 38.5 \\
\hline 1932. & 34,530 & 11,486 & 5,681 & 15,879 & 1,484 & 46.0 \\
\hline $1933 \ldots$ & 34,670 & 13,155 & 5,308 & 14,986 & 1,221 & 43.2 \\
\hline \multicolumn{7}{|l|}{ Cordoba } \\
\hline $1929 \ldots \ldots \ldots \ldots \ldots \ldots \ldots$ & 27,287 & 10,370 & 2,875 & 13,027 & 1,015 & 47.7 \\
\hline 1932. & 21,155 & 7,717 & 1,691 & 11,075 & 672 & 52.4 \\
\hline $1933 \ldots \ldots \ldots \ldots \ldots \ldots \ldots$ & 22,850 & 7,963 & 1,469 & 12,721 & 697 & 55.7 \\
\hline \multicolumn{7}{|l|}{ Entre Rios } \\
\hline $1929 \ldots \ldots \ldots \ldots \ldots \ldots \ldots$ & 22,840 & 10,113 & 4,202 & 7,341 & 1,184 & 32.1 \\
\hline $1932 \ldots \ldots \ldots$ & 17,256 & 7,465 & 3,328 & 5,480 & 983 & 31.8 \\
\hline $1933 \ldots \ldots \ldots \ldots \ldots \ldots \ldots$ & 13,880 & 6,163 & 1,918 & 5,005 & 794 & 36.1 \\
\hline \multicolumn{7}{|l|}{ La Pampa } \\
\hline $1929 \ldots \ldots \ldots \ldots \ldots \ldots$ & 8,336 & 2,931 & 2,247 & 2,986 & 172 & 35.8 \\
\hline $1932 \ldots \ldots \ldots \ldots \ldots \ldots$ & 6,385 & 2,496 & 1,248 & 2,519 & 122 & 39.5 \\
\hline $1933 \ldots \ldots \ldots \ldots \ldots \ldots \ldots$ & 5,950 & 2,171 & 994 & 2,626 & 159 & 44.1 \\
\hline \multicolumn{7}{|l|}{ Rest of the Country } \\
\hline $1929 \ldots \ldots \ldots \ldots \ldots \ldots$ & 1,145 & 559 & 89 & 427 & 70 & 37.3 \\
\hline $1932 \ldots \ldots \ldots \ldots \ldots \ldots$ & 1,775 & 954 & 133 & 603 & 85 & 34.0 \\
\hline $1933 \ldots \ldots \ldots \ldots \ldots \ldots \ldots$ & 3,330 & 1,698 & 477 & 913 & 242 & 27.4 \\
\hline
\end{tabular}

Source: Own elaboration based on Anuario Agropecuario de la Nación Argentina and Boletín Estadístico de la Provincia de Buenos Aires. 
FIGURE 11

CONTRACTS AND SHARE RENTS

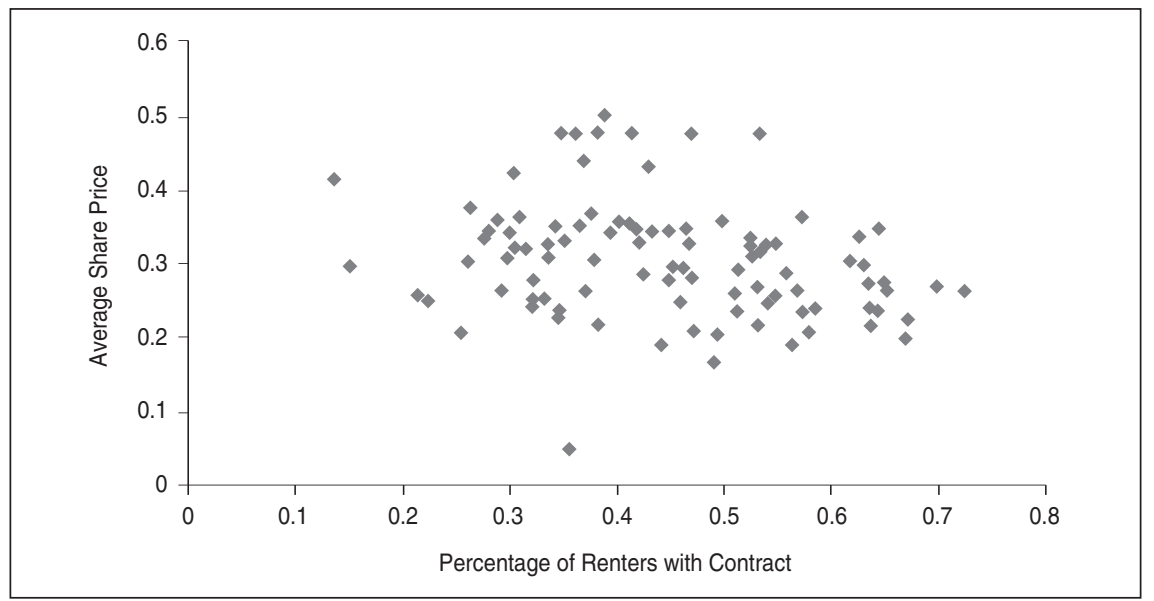

Source: Own elaboration based Boletin Estadistico de la Provincia de Buenos Aires.

\section{CONCLUSIONS}

From the late nineteenth century to 1943 we can distinguish three main periods in Argentina's political history. First, the Conservatives held power until 1912 without much political opposition in Congress because of the absence of clear and unbiased democratic rules. In this period there were no bills concerning rural rents and free contracting was the rule. Furthermore, legislative attempts to redistribute land were too weak or inefficiently designed to produce meaningful results. In the second period, from 1912 to 1930 , democracy gave the middle class a political voice. The influence of small landowners and tenants in Congress increased. The Radical party and its allies in Congress were the advocates for legislation concerning rents. The Radicals sought to improve living and market conditions for renters without imposing harsh regulation of the rental market. Even though the Radical government held the same view of the economy as the Conservatives, they supported rent legislation because of their need to maintain support in their constituencies. As in any democratic society, Congress became the place to discuss and reach consensus on reforms and legislation. Within Congress, Conservatives had veto power in the Senate and used it successfully to reduce the scope of the reforms proposed by the Radicals. The analysis presented in this paper counters the traditional notion that the Radical party legislated in favor of Conservatives' interests with a 
more nuanced view of the interplay between institutions and policy outcomes. I use evidence from the legislative process over rental legislation to show how the Conservatives turned reforms to their benefit. It is clear from the analysis that Conservatives controlled politics in small provinces but Radicals controlled the Pampean region. Accordingly, legislation responded to the different economic interests of the two regions.

In the third period, beginning with a military coup in 1930, subsequent electoral fraud allowed the Conservatives to stay in power. Most legislation, including tenancy reform, took the form of emergency legislation, because of the Great Depression and the Second World War. In the 1930s, the Antipersonalistas had a dual role, backing the Conservatives in government, but supporting some initiatives from the Radicals in Congress. By the early 1940s, the Radicals controlled Congress again and pushed for further tenancy reform. Once again, the cleavage between Radicals and Conservatives and between the Pampas and the rest of the country was decisive when it came to passing legislation. Finally, throughout the period of analysis, rental legislation was sought as complementary to markets. Furthermore, during the early years of open democracy there seemed to be a process of learning to compromise. Congress passed legislation and then reviewed it over time learning from their mistakes. The passage of the most important legislation during this period corresponds to the years in which the Radical party achieved a majority of seats in the Chamber of Deputies. Even though this legislation did not promote a revolutionary change in tenancy policy, the empirical evidence shows that it had some influence on contract decisions.

\section{REFERENCES}

\section{Primary Sources}

Cámara de Diputados, Diario de Sesiones de la Cámara de Diputados, several volumes and years. City?

Cámara de Senadores de la Nación, Diario de Sesiones del Honorable Senado de la Nación, several volumes and years. City?

Direccion General de Estadística de la Provincia de Buenos Aires, Anuario Estadístico. Dirección General de Estadística de la Provincia de Buenos Aires, several issues. La Plata.

Dirección General de Estadística de la Provincia de Buenos Aires, Boletín de la Dirección General de Estadística. Dirección General de Estadística de la Provincia de Buenos Aires, several issues. La Plata.

Ministerio de Agricultura de la Nación, Anuario Agropecuario. Ministerio de Agricultura de la Nación, Dirección de Economía Rural y Estadística, several issues. Buenos Aires. 
POLITICAL INSTITUTIONS AND ECONOMIC POLICY: RURAL RENTER LEGISLATION...

\section{Secondary Sources}

Adelman, J. (April 1992): «The Social Bases of Technical Change: Mechanization of the Wheatlands of Argentina and Canada, 1890 to 1914». Comparative Studies in Society and History 34 (2), pp. 271-300.

- (May 1992): "Socialism and Democracy in Argentina in the Age of the Second International». The HispanicAmerican Historical Review 72 (2), pp. 211-238.

- (1994): Frontier Development. Land Labour, and Capital on the Wheatlands of Argentina and Canada 1890-1914. London: Clarendon Press.

- (1999): Republic of Capita. Buenos Aires and the Legal Transformation of the Atlantic World. California: Stanford Press.

Aguinaga, C., and Azaretto, R. (1991): Ni década ni infame, del '30 al '43. Buenos Aires: Editorial Jorge Baudino.

Alesian, A., and Rosenthal, H. (1995): «Partisan Politics, Divided Government and the Economy». Political Economy of Institutions and Decisions Series. Cambridge, New York and Melbourne: Cambridge University Press.

AlhadefF, P. (1986): "The Economic Formulae of the 1930s: a Reassessment», in G. Di Tella, and D. C. M. Platt, The Political Economy of Argentina 1880-1946. New York: St. Martin's Press.

Alston, L., and Gallo, A. (2003): «The Erosion of Rule of Law in Argentina 19301947. An Explanation of Argentina's Slide from the Top 10». Working Paper.

ANSALDI, W. (1993): «¿Un caso de nomenclaturas equivocadas? Los partidos políticos después de la Ley Sáenz Peña. 1916-1930», in W. Ansaldi; A. Pucciarelly, and J. Villarruel, Argentina en la paz de dos guerras, 1914-1945. Buenos Aires: Editorial Biblos.

- (1995): «Profetas de cambios terribles. Acerca de la debilidad de la democracia Argentina, 1912-1945», in ANSALDI, and WALDO, et al. (eds.), Representaciones Inconclusas. Las clases, los actores y los discursos de la memoria, 1912-1946. Buenos Aires: Editorial Biblos.

- (comp.) (1993): Conflicto obrero-rurales pameanos 1900-1937. Vols. 1, 2, and 3. Buenos Aires: Biblioteca Política Argentina, Centro Editor de América Latina.

BALsA, J. (1992): La crisis de 1930 en el agro pampeano. Buenos Aires: Biblioteca Política Argentina, Centro Editor de América Latina.

Barsky, O., and Pucciarelli, A. (1997): «El agro pampeano. El fin de un período». Flacso, and Oficina de Publicaciones del CBC, Universidad de Buenos Aires, Buenos Aires.

Blasco, O. E. (1963): Arrendamientos y Aparcerías rurales. Disposiciones legales ordenadas, concordadas, comentadas y anotadas. Procedimiento. Buenos Aires: Ediciones Depalma.

Botana, N. (1977): El orden conservador: la política argentina entre 1880 y 1916. Buenos Aires: Sudamericana.

Botana, N.; Gallo, E., and Fernández, E. (1997): «La crisis de 1930». Buenos Aires: Serie Archivo Alvear, Instituto Torcuato Di Tella.

Canton, D. (1966): El Parlamento Argentino en épocas de cambio: 1890, 1916 y 1946. Buenos Aires: Editorial del Instituto Torcuato Di Tella.

- (1973): Elecciones y partidos políticos en la Argentina. Historia, interpretación y balance: 1910-1966. Buenos Aires: Editorial Siglo Veintiuno.

Ciria, A. (1975): Partidos y Poder en la Argentina Moderna (1930-1946). Buenos Aires: Editorial de la Flor, Third Edition. 
Cortés, C. R. (1979): El progreso argentino. Buenos Aires: Editorial Sudamericana.

- (2000): «The Vicissitudes of an Exporting Economy: Argentina, 1875-1930», in E. CÁrdenas; J. O. OCAMPo, and R. ThORP, An Economic History of Twentieth Century Latin America. Vol. 1. The Export Age: The Latin American Economies in the Late Nineteenth and Early Twentieth Centuries. Oxford: Palgrave and St. Anthony's College.

Della Paolera, G., and Taylor, A. M. (September 1999): «Economic Recovery from the Argentine Great Depression: Institutions, Expectations, and the Change of Macroeconomic Regime». The Journal of Economic History 59 (3).

- (2001): Straining the anchor. The Argentine Currency Board and the Search for Macroeconomic Stability, 1880-1935. National Bureau of Economic Research. Chicago and London: The University of Chicago Press.

Di Tella, G., and Zimelman, M. (1973): Los ciclos económicos argentinos. Buenos Aires: Paidós.

Díaz Alejandro, C. F. (1970): Essays on the Economic History of the Argentine Republic. New Haven and London: Yale University Press.

Gallo, A. (2003): «The Political Economy of Argentine Development». Ph.D. Dissertation, University of Illinois at Urbana-Champaign.

Gallo, E., and CoRTés Conde, R. (1995): Historia Argentina. La república conservadora. Buenos Aires: Editorial Paidós.

Giacobone, C., and Gallo, E. (1999): Radicalismo bonaerense, 1891-1931. La ingeniería política de Hipólito Yrigoyen. Buenos Aires: Ediciones Corregidor.

Halperin Donghi, T. (1995): «The Buenos Aires Landed Class and the Shape of Argentine Politics (1820-1930)», in E. HuBER, and F. SAFFORD, Agrarian Structure \& Political Power. Landlord \& Peasant in the Making of Latin America. Pittsburgh and London: University of Pittsburgh Press.

- (1986): «The Argentine Export Economy: Intimations of Mortality, 1894-1930», in G. Di Tella, and D. C. M. Platt, The Political Economy of Argentina 18801946. New York: St. Martin's Press.

- (2004): La república imposible (1930-1945). Buenos Aires: Editorial Ariel.

HCD Cámara de Diputados de la Nación: Diario de Sesiones de la Cámara de Diputados, several volumes and years.

HCS Cámara de Senadores de la Nación: Diario de Sesiones de la Cámara de Senadores, several volumes and years.

Hora, R. (2002): Los terratenientes de la pampa argentina. Una historia social y politica 1860-1945. Buenos Aires: Siglo Veintiuno de Argentina Editores.

Jones, M.; Saiegh, S.; Spiller, P., and Tommasi, M. (1999): «Amateur LegislatorsProfessional Politicians: The Argentine Congress». Working Paper CEDI, at http://www.udesa.edu.ar/deptodeeconomia/workp/doc31.doc.

Kofors, K. (September 1989): «Dimensions in Congressional Voting». The American Political Science Review 83 (3), pp. 949-962.

Molinelli, N. G. et al. (1999): Congreso, Presidencia y Justicia en Argentina. CEDI Fundación Gobierno y Sociedad. Buenos Aires: Temas Grupo Editorial.

O'Connell, A. (1986): «Free Trade in one (Primary Producing) Country: the Case of Argentina in the 1920s», in G. Di Tella, and D. C. M. Platt, The Political Economy of Argentina 1880-1946. New York: St. Martin's Press.

Palacio, J. M. (2001): «Judges, Lawyers, and Farmers: Uses of Justice and the Circulation of Law in Rural Buenos Aires, 1900-1940», in R. Slavatore, C.; 
Aguirre, and G. Joseph, Crime and Punishment in Latin America. Law and Society since Late Colonial Times. Durham \& London: Duke University Press.

- (January/July 2002): "La estancia mixta y el arrendamiento agrícola: Algunas hipótesis sobre su evolución histórica en la región pampeana, 1880-1945». Boletín del Instituto de Historia Argentina y Americana Dr. Emilio Ravigna, (25).

- (2004): La Paz del Trigo. Cultura legal y sociedad local en el desarrollo agropecuario pampeano. 1890-1945. Buenos Aires: Ensayo Histórico Edhasa.

PereIRA, S. (1983): En tiempos de la república agropecuaria, 1930-1943. Biblioteca Política Argentina. Buenos Aires: Centro Editor de América Latina.

Poole, K., and Rosenthal, H. (May 1984): «U.S. Presidential Elections 1968-80: A Spatial Analysis». American Journal of Political Science 28 (2), pp. 282-312.

- (May 1985): "A Spatial Model for Legislative Roll Call Analysis». American Journal of Political Science 29 (2), pp. 357-384.

- (Feb 1991): «Analysis of Congressional Coalition Patterns: A Unidimensional Model». Legislative Studies Quarterly 12 (1), pp. 55-75.

- (Feb 1991): "Patterns of Congressional Voting». American Journal of Political Science 35 (1), pp. 228-278.

Pucciarelli, A. (1993): «Conservadores, Radicales e Yirgoyenistas. Un modelo (hipotético) de hegemonía compartida 1916-1930», in A. Ansaldi; A. Pucciarelli, and J. Villarruel, Argentina en la paz de dos guerras 1914-1945. Buenos Aires: Editorial Biblos.

Pucciarelli, A., and TortTi, M. C. (1995): «La construcción de la hegemonía compartida: el enfrentamiento entre neutralistas, rupturistas e Yrigoyenistas», in W. ANSALDI, et al. (eds.), Representaciones Inconclusas. Las clases, los actores y los discursos de la memoria, 1912-1946. Buenos Aires: Editorial Biblos.

Rock, D. (1975): Politics in Argentina 1890-1930. The Rise and Fall of Radicalism. Cambridge: Cambridge University Press.

- (1975): "Radical Populism and the Conservative Elite, 1912-1930», in D. Rock (ed.), Argentina in the Twentieth Century. University of Pittsburgh Press.

- (1985): Argentina 1516-1987. Desde la colonización española hasta Alfonsín. City? Alianza Editorial.

SAnguinetTi, H. (1975): La democracia ficta, 1930-1938. Buenos Aires: Editorial Astrea.

Schillizzi Moreno, H. (1973): Argentina contemporánea. Fraude y entrega. Vols. I y II. Colección esquemas políticos. Buenos Aires: Editorial Plus Ultra.

Seltzer, A. (December 1995): "The Political Economy of the Fair Labor Standards Act of 1938». The Journal of Political Economy 103 (6), pp. 1302-1342.

Sмiтh, P. (April/June 1967): «Los radicales argentinos y la defensa de los intereses ganaderos, 1916-1930». Desarrollo Económico 7 (25), pp. 795-829.

- (1974): Argentina and the Failure of Democracy. Conflict among Political Elites. The University of Wisconsin Press.

Solberg, C. (January 1971): «Social Unrest and Agrarian Policy in Argentina, 1912 $1930 »$. Journal of Interamerican Studies and World Affairs 13 (1), pp. 18-52.

- (May 1982): «Peopling the Prairies and the Pampas: The Impact of Immigration on Argentine and Canadian Agrarian Development, 1870-1930». Journal of Interamerican Studies and World Affairs 24 (2), pp. 131-161.

- (1987): The Prairies and the Pampas. Agrarian Policy in Canada and Argentina, 1880-1930. California: Stanford University Press. 
- (1985): «Land Tenure and Land Settlement: Policy and Patterns in the Canadian Prairies and the Argentine Pampas, 1880-1930», in D. C. M. PlatT, and G. DI Tella (eds.), Argentina, Australia and Canada. Studies in Comparative Development 1870-1965. New York: St. Martin's Press.

- (1970): Immigration and Nationalism, Argentina and Chile, 1890-1914. Institute of Latin American Studies, University of Texas Press.

TAYLOR, A. (1997): "Latifundia as Malefactor in Economic Development? Scale, Tenancy and Agriculture on the Pampas, 1888-1914». Research in Economic History 17.

- (January 1997): «Peopling the Pampas: On the Impact of Mass Migration to the River Plate, 1870-1914». Explorations in Economic History 34 (1), pp. 100-132.

TAYLOR, C. C. (1948): Rural Life in Argentina. Baton Rouge: Lousiana State University Press.

Tulchin, J. C. (1986): «The Relationship between Labour and Capital in Rural Argentina, 1880-1914», in G. DI Tella, and D. C. M. PlatT, The Political Economy of Argentina 1880-1946. New York: St. Martin's Press.

Walter, R. (Nov 1984): «Politics, Parties, and Elections in Argentina's Province of Buenos Aires, 1912-1942». The Hispanic American Historical Review 64 (4), pp. 707-735.

YABLON, A. (2003): «Patronage, Corruption and Political Culture in Argentina, 1880916», Ph. D. Thesis, University of Illinois at Urbana-Champaign. 